\title{
Phenolic profile by HPLC-MS, biological potential, and nutritional value of a promising food: Monofloral bee pollen
}

\author{
Adriane Alexandre Machado De-Melo ${ }^{1}$ [1) | Leticia M. Estevinho, \\ Manuela M. Moreira ${ }^{4}$ | Cristina Delerue-Matos ${ }^{4}$ | Alex da Silva de Freitas ${ }^{5}$ \\ Ortrud Monika Barth ${ }^{6,7}$ | Ligia Bicudo de Almeida-Muradian ${ }^{1}$
}

${ }^{1}$ Department of Food and Experimental Nutrition, Pharmaceutical Sciences School, University of São Paulo, São Paulo, 05580-000, Brazil
${ }^{2}$ Agricultural College of Bragança, Polytechnic Institute of Bragança, Campus Santa Apolónia E, Bragança, 5301-855, Portugal
${ }^{3}$ Centre of Molecular and Environmental Biology, University of Minho, Campus de Gualtar, Braga, 4710-057, Portugal
${ }^{4}$ REQUIMTE/LAQV, Superior Institute of Engineering, Polytechnic Institute of Porto, Porto, 4200-072, Portugal
${ }^{5}$ Laboratory of Marine Geology, Federal Fluminense University, Niterói, 24210-340, Brazil
${ }^{6}$ Laboratory of Palynology, Department of Geology, Institute of Geosciences, Federal University of Rio de Janeiro, Rio de Janeiro, 21949-900, Brazil
${ }^{7}$ Laboratory of Viral Morphology and Morphogenesis, Oswaldo Cruz Institute, Fiocruz, Rio de Janeiro, 21040-360, Brazil

\section{Correspondence}

Adriane Alexandre Machado De-Melo, Laboratório de Análise de Alimentos da Faculdade de Ciências Farmacêuticas da USP, Avenida Professor Lineu Prestes, 580, Bloco 13-A, CEP: 05580-000, Cidade Universitária, São Paulo, SP, Brasil.

Email: adriane.melo@uol.com.br

\section{Funding information}

State of São Paulo Research Foundation (FAPESP), Grant/Award Number: Process 2011/51741-5 (AAM De-Melo);

Scholarship granted, Grant/Award Numbers: Process 2011/11746-8 and 2013/23179-6; National Council for Scientific and Technological Development (CNPq), Grant/Award Number: Process 304067/2013-0 (OM Barth); Postdoctoral fellowship financed by POPH-QREN, Grant/Award Number: SFRH/BPD/97049/ 2013 (MM Moreira)

\begin{abstract}
The objective of this study was to determine physicochemical and phenolic profiles as well the antioxidant and antimicrobial capacities of monofloral bee pollen samples from Brazil. Traditional methods were used. The phenolic profile was determined by high-performance liquid chromatography-mass spectrometry (HPLC-MS). The protein (10.6-33.9 g/100g), lipids (3.2-8.3 g/ $100 \mathrm{~g}$ ), ashes (2.6-3.8 g/100g), total phenolic (5.6-29.7 mg GAE/g), and total flavonoid (0.3$19.0 \mathrm{mg} \mathrm{QE} / \mathrm{g}$ ) values were variable, even between products with the same botanical origin. The minerals analyzed were found in amounts varying between $10 \mathrm{mg} / \mathrm{kg}$ and $9.1 \mathrm{~g} / \mathrm{kg}$. Each product presented specific color parameters. Myrcia bee pollen presented the greater antioxidant capacity, and Mimosa scabrella bee pollen from Santa Catarina state was the most efficient in inhibiting bacteria and yeasts. Among the compounds identified by HPLC-MS, flavonoid 3-O-glycosides predominated. The physicochemical and phenolic profiles of each sample were distinct, and there was no pattern between monofloral products of the same pollen type.
\end{abstract}

\section{Practical applications}

This manuscript reports physicochemical parameters, the biological potential, and the phenolic profile from HPLC-MS of some unknown monofloral bee pollen produced in Brazil. In addition to the possibility of the identification of phenolic compounds using a reliable technique, the current study helps to clarify one of the main questions of apicultural product researchers: Would monofloral bee pollens of the same botanical origin have similar profiles? Besides this, these results can increase consumer interest in this product and thus have positive impacts on apiculture in Brazil.

\section{KEYWORDS}

antimicrobial capacity, antioxidant capacity, bee products, mass spectrometry, physicochemical, polyphenols 


\section{1 | INTRODUCTION}

Apiculture is one of the few agricultural activities that serve the triple bottom line, that is, that have a positive economic, social, and environmental impact. It is extremely important to encourage it, and the most effective approach to doing this is to increase the commercial value of bee products. Bee pollen, one of the main products from apiculture, is the result of the agglomeration of hundreds and even thousands of pollen grains harvested by Apis mellifera L. bees, which use their salivary secretions as well as nectar and/or honey to agglutinate the grains (Campos et al., 2008; Komosinska-Vassev, Olczyk, Kaźmierczak, Mencner, \& Olczyk, 2015). It is common for bee pollen's physicochemical parameters to vary according to botanical origin because it is mainly composed of pollen grains (Barth et al., 2010; Campos et al., 2008).

Bee pollen contains macro- and micro-nutrients as well as compounds with biological potential, such as polyphenols. Antioxidant, antifungal, antibacterial, antiviral, anti-inflammatory, anti-osteoporosis, anti-allergic, anti-atherosclerosis, antimutagenic, immunostimulatory, hepatoprotective, and cardioprotective actions have already been attributed to these substances (Komosinska-Vassev et al., 2015). The nutritional and biological potential of bee pollen has attracted consumers looking for food supplements that are also capable of assisting in the prevention of certain diseases (Campos et al., 2008; De-Melo \& Almeida-Muradian, 2017).

The composition of bee pollen has also awakened researchers' interest; however, the variety of products marketed is so great that the physicochemical properties of many remain unknown. Additionally, the determination of the phenolic profile of bee pollen by mass spectrometry remains a little-investigated area, and compounds of high biological potential could still be discovered. Therefore, considering the nutraceutical potential of this food, the need for more information regarding bee pollen produced in Brazil and the importance of precisely identifying the phenolic compounds present in this product, the aim of the current study was to determine the physicochemical profile, as well as the phenolic profile by HPLC-MS and the antioxidant and antimicrobial capacities, of monofloral bee pollen samples collected in different locations in Brazil.

\section{2 | MATERIAL AND METHODS}

\section{$2.1 \mid$ General}

Reagents were purchased from Synth (São Paulo, SP, Brazil), and standards from Sigma-Aldrich (St. Louis, MO). The following equipment was used: nitrogen distiller (Tecnal, São Paulo, Brazil); digester block (Quimis, São Paulo, Brazil); Soxhlet extractor (Tecnal, São Paulo, Brazil); oven (Quimis, São Paulo, Brazil); ICP-OES spectrometer (Ciros Vision EOP, Spectro, Kleve, Germany); ColorQuest XE (Hunterlab, serial number: CQX 2329, Reston, VA); rotary evaporator with a vacuum system (Buchi, RE-111 and B-461, Flawil, Switzerland); spectrophotometer Shimadzu UV 1650 PC (Kyoto, Japan) for total phenolic, total flavonoid, and antioxidant capacity; spectrophotometer Varian UV-Visible Spectrophotometer Cary 50 Scan (California) for antimicrobial capacity; mass spectrometer LTQ Orbitrap XL (Bremen, Germany); as well as Shimadzu HPLC system (Software LabSolutions, Kyoto, Japan), with a column oven (CTO-10AS VP), an injection system (LC-20AD), an autosampler (SIL-20A HT), and a photodiode array detector (PDA) (SPD-M20A).

\section{2 | Bee pollen samples}

Eight monofloral bee pollen samples were produced by Apis mellifera bees in seven Brazilian states from April 2012 to September 2013 and subsequently collected and processed by beekeepers. Processing of the samples involved a dehydration step, in which, according to the producers, the temperatures ranged from 40 to $50^{\circ} \mathrm{C}$. The products were sent to the Food Analysis Laboratory (FAL) of the Faculty of Pharmaceutical Sciences at the University of São Paulo (São Paulo, Brazil), where they were coded.

A portion of each sample was sent to the Palynology Laboratory (PL) of the Institute of Geosciences at the Federal University of Rio de Janeiro (Rio de Janeiro, Brazil) to confirm its botanical origin; another portion was sent to the Microbiology Laboratory $(\mathrm{ML})$ of the Agrarian School at the Polytechnic Institute of Bragança (Bragança, Portugal) to determine its antimicrobial capacity as well as to identify and quantify the phenolic compounds by HPLC-MS; and a third portion was sent to the Agricultural and Environmental Technology Center (AETC) (Porangatu, Brazil) to analyze its mineral content. The samples were transported at room temperature and then stored at $-4^{\circ} \mathrm{C}$ (FAL and $\mathrm{ML}$ ) or at room temperature (PL and $\mathrm{AETC}$ ). Before each analysis, the samples were crushed and sieved through a $0.595 \mathrm{~mm}$ sieve. It was not necessary to crush the bee pollen used to prepare methanolic extracts.

The botanical origin of the bee pollen was confirmed using the methodology proposed by Barth et al. (2010). All samples were classified as monofloral, since they had more than $90 \%$ of a unique pollen type. The code, the location, date of collection, and the botanical origin of the eight bee pollen samples from seven Brazilian states are presented in Table 1.

\section{3 | Physicochemical parameters}

Nitrogen concentration was determined by the micro-Kjeldahl method, and a factor of 6.25 was used to convert the value into protein. Ethereal extract (lipids) was determined by Soxhlet extraction method using diethyl ether as a solvent. Ashes were determined by the incineration of samples in an oven at $550^{\circ} \mathrm{C}$ for $8 \mathrm{hr}$ (Almeida-Muradian, Arruda, \& Barreto, 2012).

The minerals were extracted from a $500 \mathrm{mg}$ sample by acid digestion with nitric acid and perchloric acid $(2: 1 \mathrm{v} / \mathrm{v})$ in an open system. Then, the iron, copper, calcium, magnesium, zinc, manganese, sodium, and potassium concentrations were determined by inductively coupled plasma optical emission spectrometry (ICP-OES) as described by Morgano et al. (2012). The following operating parameters were used: forward power of $1.45 \mathrm{~kW}$; cooling air flow rate of $12 \mathrm{~L} / \mathrm{min}$; auxiliary argon flow of $1 \mathrm{~L} / \mathrm{min}$; nebulizer air flow rate of $1 \mathrm{~L} / \mathrm{min}$; and sample flow rate of $2 \mathrm{~mL} / \mathrm{min}$. The wavelengths were specific for each element 
TABLE 1 Geographical origin, collection date and frequency of the pollen types of eight monofloral bee pollen samples produced in seven Brazilian states

\begin{tabular}{llll}
\hline Sample/code & Geographical origin & Collection date & Pollen types (frequency) \\
\hline Ala & Ribeirão Preto, São Paulo & Jun to Jul/13 & Alternanthera (94.2\%) \\
\hline Ana & Ribeirão Preto, São Paulo & Aug to Sep/13 & $\begin{array}{l}\text { Anadenanthera (95\%), } \\
\text { Schinus (3.4\%) }\end{array}$ \\
\hline Cna & Una, Bahia & Sep/12 & Cocos nucifera (97.5\%) \\
\hline Mca & Neópolis, Sergipe & Apr to May/12 & $\begin{array}{l}\text { Mimosa caesalpiniaefolia (96.3\%), } \\
\text { Cocos nucifera (3.7\%) }\end{array}$ \\
\hline Mya & Arvorezinha, Rio Grande do Sul & Nov/12 & Myrcia (99.5\%) \\
\hline MsaSC & Fraiburgo, Santa Catarina & Sep/12 & Mimosa scabrella (95.5\%) \\
\hline MsaRN & Taipu, Rio Grande do Norte & Oct/12 & Mimosa scabrella (98.7\%) \\
MsaMT & Cáceres, Mato Grosso & Sep/13 & Mimosa scabrella (100\%)
\end{tabular}

and a calibration curve was prepared with different concentrations of each mineral.

The instrumental color parameters were determined by reflectance using ColorQuest XE equipment operating CIE Lab [L*: 0-100, $a^{*}:(-)$ blue to $(+)$ red, and $b^{*}:(-)$ green to $(+)$ yellow] with Universal Software V4.10. The analyses were performed in a $50 \mathrm{~mm}$ quartz cuvette and the results were expressed as $L^{*} a^{*} b^{*}$ color parameters.

\subsection{Preparation of extracts}

The ethanolic extracts (ETE) and the methanolic extracts (MEE) were obtained using traditional methods (Carpes et al., 2008; De-Melo et al., 2016; Morais, Moreira, Feás, \& Estevinho, 2011). For ETE, an ethanol solution (ethanol : distilled water, 70:30 v/v) was used, and only methanol was used for the MEE. All extractions were performed in triplicates, and the extracts were stored in an amber glass at $-4^{\circ} \mathrm{C}$ until analysis.

\subsection{Total phenolic and total flavonoid contents}

The ETE were analyzed according to Carpes et al. (2008), with the modifications proposed by De-Melo et al. (2016). All readings were performed with a spectrophotometer operating at $20^{\circ} \mathrm{C}$. For the total phenolic content, a gallic acid standard curve was constructed to express the results in mg of gallic acid equivalents (GAE) per $g$ of the sample. For the total flavonoid content, a quercetin standard curve was constructed, and the results were expressed in $\mathrm{mg}$ of quercetin equivalents $(\mathrm{QE})$ per $g$ of the sample.

\subsection{Antioxidant capacity}

Two methods were used to determine the antioxidant capacity of the ETE. 2,-dipheny-1-picrylhydrazyl (DPPH) assay was performed according to Brand-Williams, Cuvelier, and Berset (2005) while considering the modifications proposed by De-Melo et al. (2016), and the oxygen radical absorbance capacity (ORAC) assay was conducted according to the procedure described by Huang, Ou, and Prior (2005), with the modifications also proposed by De-Melo et al. (2016). Different concentrations of Trolox were prepared to construct a standard curve, and the results were expressed in $\mu \mathrm{mol}$ of Trolox equivalents (TE) per gram of the sample.

\section{$2.7 \mid$ Antimicrobial capacity}

The MEE were tested against American Type Culture Collection (ATCC) strains (LGC Standards S.L.U., Barcelona, Spain): Escherichia coli $25922^{\mathrm{TM}}$, Klebsiella BAA1705 ${ }^{\mathrm{TM}}$, Streptococcus pyogenes $12344^{\mathrm{TM}}$, Staphylococcus aureus $25923^{\mathrm{TM}}$, and Candida albicans $60193^{\mathrm{TM}}$. The extracts were also tested against bacteria and yeasts isolated from biological fluids and identified in the Northeast Hospital Centre, Bragança, Portugal: E. coli ESA72, Klebsiella ESA61, S. pyogenes ESA12, S. aureus ESA54, and C. albicans ESA109. The microorganisms were stored and prepared according to the conditions described by De-Melo et al. (2016).

For analysis, the inoculum was transferred to an Erlenmeyer flask containing a sodium chloride solution $(0.85 \mathrm{~g} / 100 \mathrm{~mL}$ of distilled water). Then, the solution was adjusted to 0.5 on the MacFarland scale, confirmed by a spectrophotometric reading at $580 \mathrm{~nm}$ for bacteria and $640 \mathrm{~nm}$ for yeasts. Cell suspensions were finally diluted to $10^{4} \mathrm{CFU} /$ $\mathrm{mL}$, and the tests were carried out according to the method described by Morais et al. (2011). Fluconazole and gentamicin were used as positive controls. The results were expressed as minimum inhibitory concentration (MIC), that is, the lowest concentration of MEE that inhibited visible growth of microorganisms.

\subsection{Identification and quantification of phenolic compounds}

The ETE were analyzed to determine their phenolic profile using a mass spectrometer equipped with an electrospray ionization source and controlled by software LTQ Tune Plus 2.5 .5 as well as Xcalibur 2.1.0. The instrument was operated in a negative-ion mode, the capillary (sprayer) voltage was set at $2,800 \mathrm{~V}$, and the capillary temperature was set at $275^{\circ} \mathrm{C}$. The flow rates of the sheath gas and the auxiliary gas (both nitrogen) were adjusted to 40 and 10 (arbitrary units), respectively. Electrospray ionization was performed at a capillary voltage of $-28 \mathrm{~V}$ and a tube lens voltage of $-150 \mathrm{~V}$. The full scan covered the 


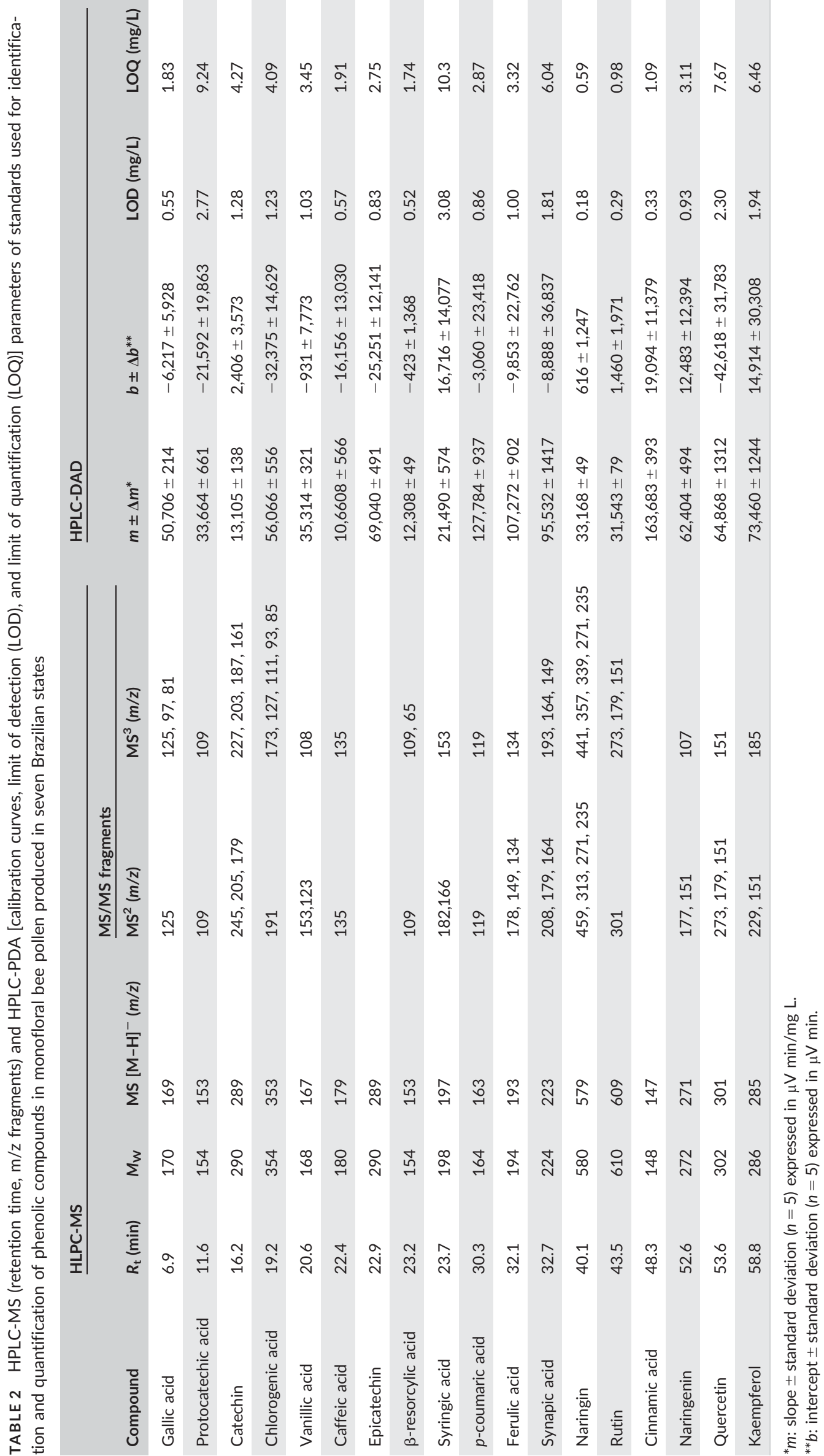


TABLE 3 Nutritive value (dry-matter basis) and instrumental color parameters of monofloral bee pollen samples produced in seven Brazilian states

\begin{tabular}{|c|c|c|c|c|c|c|c|c|}
\hline \multirow[b]{2}{*}{ Parameters } & \multicolumn{8}{|l|}{ Samples $^{1}$} \\
\hline & Ala & Ana & Cna & Mca & Mya & MsaSC & MsaRN & MsaMT \\
\hline Proteins (g/100 g) & $10.6 \pm 0.4^{g}$ & $16.0 \pm 0.1^{\mathrm{d}}$ & $11.8 \pm 0.3^{f}$ & $17.6 \pm 0.1^{c}$ & $22.2 \pm 0.1^{\mathrm{b}}$ & $14.4 \pm 0.2^{\mathrm{e}}$ & $11.7 \pm 0.1^{f}$ & $33.9 \pm 0.1^{\mathrm{a}}$ \\
\hline Ashes (g/100 g) & $3.1 \pm 0.2^{d}$ & $3.0 \pm 0.1^{\mathrm{d}, \mathrm{e}}$ & $3.5 \pm 0.0^{b}$ & $3.8 \pm 0.1^{a}$ & $2.6 \pm 0.0^{f}$ & $2.8 \pm 0.0^{\mathrm{e}}$ & $3.2 \pm 0.1^{c, d}$ & $3.4 \pm 0.0^{b, c}$ \\
\hline \multicolumn{9}{|l|}{ Minerals } \\
\hline $\mathrm{Mg}(\mathrm{g} / \mathrm{kg})$ & $0.9 \pm 0.0^{e}$ & $1.5 \pm 0.1^{\mathrm{c}, \mathrm{d}}$ & $2.3 \pm 0.1^{a}$ & $1.6 \pm 0.0^{b, c}$ & $1.3 \pm 0.1^{d}$ & $1.3 \pm 0.1^{d}$ & $0.9 \pm 0.1^{\mathrm{e}}$ & $1.8 \pm 0.1^{b}$ \\
\hline $\mathrm{Na}(\mathrm{mg} / \mathrm{kg})$ & $41.4 \pm 1.4^{\mathrm{e}}$ & $40.8 \pm 2.3^{\mathrm{e}}$ & $52.3 \pm 1.3^{d}$ & $148.5 \pm 2.2^{c}$ & $43.9 \pm 1.3^{\mathrm{e}}$ & $38.0 \pm 1.1^{\mathrm{e}}$ & $98.1 \pm 1.6^{c}$ & $279.3 \pm 2.0^{a}$ \\
\hline $\mathrm{Zn}(\mathrm{mg} / \mathrm{kg})$ & $50.8 \pm 2.7^{d}$ & $99.0 \pm 2.7^{\mathrm{a}}$ & $72.6 \pm 2.1^{c}$ & $88.7 \pm 2.7^{b}$ & $67.6 \pm 3.0^{c}$ & $72.6 \pm 2.7^{c}$ & $65.6 \pm 2.8^{c}$ & $72.5 \pm 2.0^{c}$ \\
\hline $\mathrm{Fe}(\mathrm{mg} / \mathrm{kg})$ & $1,017.5 \pm 5.1^{a}$ & $466.3 \pm 5.0^{b}$ & $109.0 \pm 1.6^{e}$ & $79.4 \pm 0.6^{g}$ & $142.2 \pm 3.8^{d}$ & $187.7 \pm 1.9^{c}$ & $94.5 \pm 2.2^{f}$ & $78.9 \pm 0.5^{g}$ \\
\hline $\mathrm{Mn}(\mathrm{mg} / \mathrm{kg})$ & $50.8 \pm 4.3^{e}$ & $89.1 \pm 2.8^{c}$ & $94.7 \pm 2.8^{c}$ & $69.3 \pm 3.3^{d}$ & $43.5 \pm 1.6^{\mathrm{e}}$ & $112.3 \pm 6.9^{b}$ & $86.4 \pm 2.2^{c}$ & $314.0 \pm 5.9^{a}$ \\
\hline $\mathrm{Cu}(\mathrm{mg} / \mathrm{kg})$ & $10.0 \pm 0.6^{e}$ & $11.3 \pm 0.6^{\mathrm{b}, \mathrm{c}, \mathrm{d}}$ & $11.6 \pm 0.0^{b, c}$ & $10.8 \pm 0.0^{\mathrm{b}, \mathrm{c}, \mathrm{d}, \mathrm{e}}$ & $17.1 \pm 0.6^{a}$ & $11.8 \pm 0.0^{b}$ & $10.2 \pm 0.6^{\mathrm{c}, \mathrm{d}, \mathrm{e}}$ & $11.5 \pm 0.6^{b, c}$ \\
\hline$b^{*}(-$ or +$)$ & $48.8 \pm 0.7^{b}$ & $41.2 \pm 0.1^{c}$ & $31.5 \pm 0.2^{\mathrm{g}}$ & $35.4 \pm 0.3^{f}$ & $48.3 \pm 0.1^{b}$ & $54.5 \pm 0.4^{a}$ & $36.9 \pm 0.3^{e}$ & $39.0 \pm 0.4^{d}$ \\
\hline
\end{tabular}

${ }^{1}$ Ala, Alternanthera; Ana, Anadenanthera; Cna, Cocos nucifera; Mca, Mimosa caesalpiniaefolia; Mya, Myrcia; MsaSC, Mimosa scabrella from Santa Catarina; MsaRN, Mimosa scabrella from Rio Grande do Norte; MsaMT, Mimosa scabrella from Mato Grosso.

Values correspond to the average \pm standard deviation of three replicates. Averages followed by the same letter are not significantly different $(p>.05)$.

mass range from $\mathrm{m} / \mathrm{z} 100$ to 1,000. Fragmentation experiments were performed using the iron trap with helium as the collision gas. The compounds were identified by comparing the spectra with phenolic standards and MS database (literature). The data generated by the analysis of the phenolic standards are presented in Table 2.

The quantification of phenolic compounds was carried out based on the procedure described by Rubilar, Pinelo, Shene, Sineiro, and Nuñez (2007), with some modifications. The HPLC system used was a Shimadzu equipped with Phenomenex Gemini $\mathrm{C}_{18}$ reversed phase column $(250 \times 4.6 \mathrm{~mm}, 5 \mu \mathrm{m})$ (Torrance, The United States). The ETE were filtered using a $0.22 \mu \mathrm{m}$ nylon filter (Millipore, São Paulo, Brazil), and $20 \mu \mathrm{L}$ of them was injected into the HPLC system. The mobile phase was composed of water (solvent A) and methanol (solvent B) that were both acidified with $0.1 \%$ formic acid, filtered using a $0.45 \mu \mathrm{m}$ nylon filter (Whatman, Maidstone, The United Kingdom) and degassed in a sonicator for $10 \mathrm{~min}$. The mobile phase flow rate was $1 \mathrm{~mL} / \mathrm{min}$, and the elution in the gradient mode occurred as follows: 0 min, $15 \% \mathrm{~B}$ in $A ; 20$ min, 30\% B in $A ; 40$ min, 45\% B in $A ; 45$ min, 50\% B in $A ; 50$ $\min , 55 \% \mathrm{~B}$ in $\mathrm{A} ; 65 \mathrm{~min}, 70 \% \mathrm{~B}$ in $\mathrm{A}$; and $75-80 \mathrm{~min}, 100 \% \mathrm{~B}$. Then, the system returned to the initial conditions to stabilize the column, whose temperature was maintained at $25^{\circ} \mathrm{C}$.

The concentrations of some compounds were determined from a standard curve constructed with different concentrations of the standards in a methanol solution (methanol : water, 50:50 mL:mL). The standards were chosen based on the literature. The parameters of the calibration curves, limit of detection (LOD) and limit of quantification (LOQ) are presented in Table 2. The correlation coefficient $\left(r^{2}\right)$ was at least .99. Detection was performed by scanning between 190 and $600 \mathrm{~nm}$, and quantification was carried out at 280,320 as well as $360 \mathrm{~nm}$ depending on the maximum absorption of the identified compound. The results were expressed as $\mathrm{mg}$ of a compound per $100 \mathrm{~g}$ of a sample.

\section{9 | Statistical analyses}

All analyses were performed in triplicate, and the results were presented as means \pm standard deviation. ANOVA followed by Student's $t$ test were used to identify differences at a significance level of $5 \%$. All statistical analyses were performed using the SAS software (version 9.0, SAS Institute, Inc., Cary, NC).

\section{3 | RESULTS AND DISCUSSION}

\section{1 | Physicochemical parameters}

The physicochemical parameters of the eight bee pollen samples from seven Brazilian states are presented in Table 3. The Fe content in the Alternanthera (Ala) sample $(1,017.5 \pm 5.1 \mathrm{mg} / \mathrm{kg})$ was $2-12$ times greater than values observed in the other samples $(78.9 \pm 0.5$ to $466.3 \pm 5.0 \mathrm{mg} / \mathrm{kg}$ ). In bee pollen, the Fe level can vary from 11.1 to $1,290 \mathrm{mg} / \mathrm{kg}$, according to the botanical origin of the samples, the season and, principally, the soil characteristics of where the plant grew (De-Melo \& Almeida-Muradian, 2017; Morgano et al., 2012). To the best of our knowledge, high Fe levels in Brazilian bee pollen have never been related to environmental pollution; therefore, the Fe content in the eight samples can be considered nutritionally interesting, since in a portion of only $25 \mathrm{~g}, 2-25 \mathrm{mg}$ of this mineral was found.

The $\mathrm{Zn}$ levels in samples were similar to those observed in Zea mays monofloral bee pollen from Australia (48 mg/kg) and from Egypt ( $80 \mathrm{mg} / \mathrm{kg}$ ), in heterofloral bee pollen from Argentina (23-106 mg/kg) 
(De-Melo \& Almeida-Muradian, 2017), and in Brassica monofloral bee pollen samples produced in Brazil (64.1-76.2 mg/kg) (De-Melo, 2015). The highest $\mathrm{Zn}$ level was found in the Anadenanthera (Ana) sample $(99.0 \pm 2.7 \mathrm{mg} / \mathrm{kg})$, and the lowest level was in the Ala sample $(50.8 \pm$ $2.7 \mathrm{mg} / \mathrm{kg}$ ). In the case of Ana and Ala samples, we suggest that all the differences observed in their compositions are related to botanical origin, because both were produced in the same apiary, same soil conditions, during winter, and with identical processing practices.

The highest $\mathrm{Ca}(3.9 \pm 0.1 \mathrm{~g} / \mathrm{kg}), \mathrm{Mg}(2.3 \pm 0.1 \mathrm{~g} / \mathrm{kg})$, and $L^{*}$ parameter $(71.7 \pm 0.4)$ values were observed in the Cocos nucifera (Cna) sample. These results corroborate those observed by De-Melo (2015), who, using an exploratory multivariate approach to physicochemical parameters of 56 samples from different regions of Brazil, identified the tendency for Cocos nucifera monofloral bee pollen to have elevated levels of $\mathrm{Ca}, \mathrm{Mg}$, and $L^{*}$. One of the highest lipid values $(8.3 \pm 0.3 \mathrm{~g} /$ $100 \mathrm{~g}$ ) were also identified in the Cna sample. In bee pollen, this parameter can reach $22 \mathrm{~g} / 100 \mathrm{~g}$, and there is a strong influence of botanical origin on the values (De-Melo \& Almeida-Muradian, 2017); however, the dehydration techniques adopted by the beekeeper can influence the extraction of these compounds at the time of analysis and, consequently, the result (De-Melo et al., 2016).

The highest ashes $(3.8 \pm 0.1 \mathrm{~g} / 100 \mathrm{~g})$ and $K$ values $(9.1 \pm 0.1 \mathrm{~g} / \mathrm{kg})$ were observed in the Mimosa caesalpiniaefolia (Mca) sample. The $K$ level in bee pollen can vary from 1.4, as observed by Morgano et al. (2012) in a heterofloral bee pollen produced in Brazil, to $38 \mathrm{~g} / \mathrm{kg}$, a value quantified in a monofloral bee pollen from Asphodelus fistulosus produced in Australia (De-Melo \& Almeida-Muradian, 2017). Melo, Freitas, Barth, and Almeida-Muradian (2009) observed a negative correlation between the pollen type $M$. caesalpiniaefolia and the lipid content in bee pollen from Brazil, which could explain the fact that one of the lowest levels of this nutrient was found in the Mca sample (4.9 g/100 g).

The highest $\mathrm{Cu}$ content was found in the Myrcia (Mya) sample $(17.1 \pm 0.6 \mathrm{mg} / \mathrm{kg})$ as well as the lowest values for ashes $(2.6 \pm$ $0.0 \mathrm{~g} / 100 \mathrm{~g}), \mathrm{Ca}(1.1 \pm 0.0 \mathrm{~g} / \mathrm{kg})$, and $\mathrm{Mn}(43.5 \pm 1.6 \mathrm{mg} / \mathrm{kg})$. Generally, this food contained elevated levels of $\mathrm{Cu}$, varying from 3 to $42 \mathrm{mg} / \mathrm{kg}$ (De-Melo \& Almeida-Muradian, 2017). In monofloral samples from Eucalyptus bridgesiana collected in Australia, the average content for this mineral was $16.5 \mathrm{mg} / \mathrm{kg}$, whereas it varied from 5.6 to $23.9 \mathrm{mg} / \mathrm{kg}$ in Poland (De-Melo \& Almeida-Muradian, 2017) and oscillated between 3.2 and $25.4 \mathrm{mg} / \mathrm{kg}$ in other studies with Brazilian samples (Morgano et al., 2012).

The physicochemical parameters of the Mimosa scabrella monofloral samples varied between harvesting regions, possibly due to the pollen composition of the plants of this species being variable. In the $M$. scabrella from Rio Grande do Norte (MsaRN) sample, the $\mathrm{K}$ content was more pronounced $(9.1 \pm 0.1 \mathrm{~g} / \mathrm{kg})$. The M. scabrella from Santa Catarina (MsaSC) sample had the highest $b^{*}$ value $(54.5 \pm 0.4)$, that is, a more intense tonality of yellow, whereas in the M. scabrella from Mato Grosso (MsaMT) sample, the $a^{*}$ value $(10.0 \pm 0.1)$ was the highest among the samples, indicating a more intense tonality of red. The MsaMT sample also had the highest values of $\mathrm{Mn}(314.0 \pm 5.9 \mathrm{mg} / \mathrm{kg})$, $\mathrm{Na}(279.3 \pm 2.0 \mathrm{~g} / \mathrm{kg})$, and protein $(33.9 \pm 0.1 \mathrm{~g} / 100 \mathrm{~g})$ among the three M. scabrella monofloral bee pollen samples. In bee pollen, protein levels can vary from 10 to $40 \mathrm{~g} / 100 \mathrm{~g}$, depending on the botanical origin (Campos et al., 2008); thus, the values observed not only in Msa samples but also in the others are within the expected range.

The Mn content in the Msa samples $(86.4 \pm 2.2$ to $314 \pm 5.9 \mathrm{mg} /$ $\mathrm{kg}$ ) should be emphasized. In bee pollen, the content of this mineral can reach $429.8 \mathrm{mg} / \mathrm{kg}$, which is the value cited by De-Melo and Almeida-Muradian (2017) in samples collected in China. As far as we know, in Brazil, the highest Mn content observed until then was that found in the present study. Furthermore, all the samples contain a significant quantity of this mineral.

Based on the results of the present study and the literature, it is not possible to establish a physicochemical profile that would be characteristic of M. scabrella monofloral bee pollen produced in Brazil. This is possibly because there are differences in pollen composition, which can be related to genotypic variations and/or different environmental conditions during plant development.

The fact that all samples had low sodium content should be highlighted. All over the world, there exists a preoccupation with an excessive sodium intake, frequently correlated with the consumption of processed and industrialized foods. A portion of $25 \mathrm{~g}$ of the analyzed sample provides only approximately $0.05-0.3 \%$ of the maximum $2 \mathrm{~g} /$ day intake of Na recommended by the OMS (WHO, 2012).

\section{2 | Biological potential}

The biological activity indicators are presented in Table 4 . The more elevated phenolic and total flavonoid levels were observed in the Mya bee pollen: $29.7 \pm 0.3 \mathrm{mg} \mathrm{GAE} / \mathrm{g}$ and $19.0 \pm 0.6 \mathrm{mg} \mathrm{QE} / \mathrm{g}$, respectively. At the same time, the lowest values were observed in the Cna (total phenolics: $5.6 \mathrm{mg} \pm 0.0 \mathrm{GAE} / \mathrm{g}$ ) and MsaMT (total flavonoid: $0.3 \pm$ $0.0 \mathrm{mg}$ QE/g) samples. As observed by De-Melo (2015), bee pollen with a predominance of Cocos nucifera produced in Brazil seems to have a tendency toward low levels of total phenolic.

In previous studies, the total phenolic content varied from 5.4 to $132.4 \mathrm{mg} \mathrm{GAE} / \mathrm{g}$, and the total flavonoid content between 0.6 and $27.2 \mathrm{mg}$ QE/g in bee pollen from Brazil (Menezes, Maciel, Miranda, \& Druzian, 2010; Vecchia, Pegoraro, Carpes, \& Pegoraro, 2009). In Portugal, the values fluctuated between 10.5 and $45.9 \mathrm{mg} \mathrm{GAE} / \mathrm{g}$ (total phenolic) as well as between 4.5 and $7.1 \mathrm{mg}$ QE/g (total flavonoid) (Féas, Vázquez-Tato, Estevinho, Seijas, \& Iglesias, 2012; Morais et al., 2011). Mărghitas et al. (2009), who analyzed monofloral bee pollen samples produced in Romania, observed total phenolic values between 4.4 and $16.4 \mathrm{mg} \mathrm{GAE} / \mathrm{g}$ as well as total flavonoid between 3.8 and $13.6 \mathrm{mg}$ $\mathrm{QE} / \mathrm{g}$. The variation observed in these parameters could be due to the botanical origin of the samples and the processing conditions adopted by the beekeepers (Campos et al., 2008; De-Melo et al., 2016).

The Mya sample also presented a greater antioxidant capacity (ORAC: $542.0 \pm 20.7 \mu \mathrm{mol}$ TE/g and DPPH: $110.8 \pm 1.3 \mu \mathrm{mol}$ TE/g) and was one of the products with the greatest antimicrobial capacity against yeasts (MIC: $11.5 \pm 0.3$ to $13.3 \pm 1.0 \mathrm{mg} / \mathrm{mL}$ ). The antioxidant capacity of the eight samples, by the DPPH method, was below that observed by Mărghitas et al. (2009) in samples collected in Romania (135-2,814 $\mu \mathrm{mol} \mathrm{TE} / \mathrm{g})$. By ORAC, the values were close to those 
TABLE 4 Total phenolics, total flavonoids, antioxidant, and antimicrobial capacities (dry-matter basis) of monofloral bee pollen samples produced in seven Brazilian states

\begin{tabular}{|c|c|c|c|c|c|c|c|c|}
\hline \multirow[b]{2}{*}{ Parameters } & \multicolumn{8}{|l|}{ Samples ${ }^{1}$} \\
\hline & Ala & Ana & Cna & Mca & Mya & MsaSC & MsaRN & MsaMT \\
\hline Total phenolics (mg GAE/g) & $11.2 \pm 1.0^{\mathrm{e}}$ & $16.1 \pm 1.1^{\mathrm{b}}$ & $5.6 \pm 0.0^{g}$ & $12.7 \pm 0.4^{c}$ & $29.7 \pm 0.3^{\mathrm{a}}$ & $11.3 \pm 0.4^{\mathrm{d}, \mathrm{e}}$ & $7.4 \pm 0.3^{f}$ & $12.5 \pm 0.3^{c, d}$ \\
\hline Total flavonoids (mg QE/g) & $1.0 \pm 0.1^{d}$ & $1.3 \pm 0.1^{c}$ & $1.1 \pm 0.0^{d}$ & $1.3 \pm 0.0^{c, d}$ & $19.0 \pm 0.6^{\mathrm{a}}$ & $1.5 \pm 0.0^{c}$ & $4.1 \pm 0.1^{b}$ & $0.3 \pm 0.0^{\mathrm{e}}$ \\
\hline \multicolumn{9}{|l|}{ Antioxidant capacity } \\
\hline $\begin{array}{l}\text { DPPH ( } \mu \mathrm{mol} \mathrm{TE} / \mathrm{g}) \\
\text { ORAC }(\mu \mathrm{mol} \mathrm{TE} / \mathrm{g})\end{array}$ & $\begin{array}{r}15.5 \pm 0.3^{\mathrm{e}} \\
178.3 \pm 8.6^{\mathrm{d}}\end{array}$ & $\begin{array}{r}26.8 \pm 0.6^{d} \\
299.6 \pm 4.6^{b}\end{array}$ & $\begin{array}{c}10.0 \pm 0.3^{f} \\
156.9 \pm 4.4^{\mathrm{d}, \mathrm{e}}\end{array}$ & $\begin{array}{r}25.6 \pm 1.3^{d} \\
224.1 \pm 7.4^{c}\end{array}$ & $\begin{array}{l}110.8 \pm 1.3^{a} \\
542.0 \pm 20.7^{a}\end{array}$ & $\begin{array}{r}71.6 \pm 1.8^{b} \\
313.3 \pm 8.9^{b}\end{array}$ & $\begin{array}{r}31.6 \pm 0.0^{c} \\
232.9 \pm 8.6^{c}\end{array}$ & $\begin{array}{r}15.9 \pm 0.1^{\mathrm{e}} \\
133.7 \pm 7.3^{\mathrm{e}}\end{array}$ \\
\hline \multicolumn{9}{|c|}{ Antimicrobial capacity ${ }^{2}\left(\mathrm{MIC}^{3}: \mathrm{mg} / \mathrm{mL}\right)$} \\
\hline Sp ESA12 & $4.6 \pm 0.5^{b, c}$ & $5.2 \pm 0.5^{\mathrm{a}, \mathrm{b}}$ & $5.3 \pm 0.7^{a, b}$ & $4.3 \pm 1.0^{b, c}$ & $4.7 \pm 0.5^{\mathrm{a}, \mathrm{b}}$ & $1.4 \pm 0.5^{\mathrm{e}}$ & $2.8 \pm 0.6^{d}$ & $4.0 \pm 0.6^{c}$ \\
\hline Sp 12344 & $2.6 \pm 0.7^{b, c}$ & $3.9 \pm 0.7^{a}$ & $4.3 \pm 1.0^{\mathrm{a}}$ & $2.4 \pm 0.7^{b, c}$ & $3.0 \pm 0.6^{\mathrm{a}, \mathrm{b}}$ & $1.1 \pm 0.3^{d}$ & $2.3 \pm 0.6^{c}$ & $3.1 \pm 0.5^{\mathrm{a}, \mathrm{b}}$ \\
\hline Sa ESA54 & $5.0 \pm 0.4^{\mathrm{c}, \mathrm{d}}$ & $6.4 \pm 0.7^{\mathrm{a}, \mathrm{b}}$ & $6.8 \pm 1.0^{a}$ & $5.3 \pm 0.9^{b, c, d}$ & $5.6 \pm 0.5^{\mathrm{b}, \mathrm{c}}$ & $2.2 \pm 0.4^{\mathrm{e}}$ & $5.6 \pm 0.8^{b, c, d}$ & $4.8 \pm 0.5^{d}$ \\
\hline Sa 25923 & $3.5 \pm 0.2^{c}$ & $5.0 \pm 1.0^{\mathrm{a}, \mathrm{b}}$ & $5.7 \pm 0.2^{\mathrm{a}}$ & $3.3 \pm 0.7^{c}$ & $4.3 \pm 0.9^{\mathrm{a}, \mathrm{b}, \mathrm{c}}$ & $1.6 \pm 0.2^{d}$ & $4.2 \pm 0.1^{\mathrm{a}, \mathrm{b}, \mathrm{c}}$ & $3.6 \pm 0.4^{b, c}$ \\
\hline Ec ESA72 & $5.4 \pm 0.4^{b, c}$ & $6.8 \pm 0.2^{a, b}$ & $8.4 \pm 0.7^{a}$ & $5.4 \pm 0.4^{b, c}$ & $6.6 \pm 0.6^{b, c}$ & $2.9 \pm 0.4^{d}$ & $6.7 \pm 1.1^{\mathrm{b}, \mathrm{c}}$ & $5.3 \pm 0.3^{c}$ \\
\hline Ec 25922 & $4.0 \pm 0.4^{b}$ & $5.6 \pm 0.8^{a}$ & $5.7 \pm 0.2^{\mathrm{a}}$ & $3.9 \pm 0.9^{b, c}$ & $5.2 \pm 0.2^{\mathrm{a}, \mathrm{b}}$ & $2.2 \pm 0.6^{c}$ & $5.0 \pm 0.8^{\mathrm{a}, \mathrm{b}}$ & $4.3 \pm 0.4^{\mathrm{a}, \mathrm{b}}$ \\
\hline K ESA61 & $6.5 \pm 0.5^{b}$ & $7.3 \pm 0.4^{b}$ & $9.3 \pm 0.7^{a}$ & $6.3 \pm 0.2^{b}$ & $7.2 \pm 0.9^{b}$ & $4.0 \pm 0.5^{c}$ & $6.9 \pm 0.2^{b}$ & $6.1 \pm 0.5^{b}$ \\
\hline K 1705 & $4.1 \pm 0.8^{\mathrm{d}, \mathrm{e}}$ & $6.1 \pm 0.6^{a, b}$ & $7.4 \pm 0.7^{a}$ & $4.6 \pm 0.2^{c, d}$ & $5.8 \pm 0.5^{\mathrm{b}, \mathrm{c}}$ & $2.9 \pm 0.4^{e}$ & $6.0 \pm 0.1^{\mathrm{a}, \mathrm{b}, \mathrm{c}}$ & $4.9 \pm 0.7^{\mathrm{b}, \mathrm{c}}$ \\
\hline Ca SA109 & $12.6 \pm 1.7^{d}$ & $18.9 \pm 2.4^{b}$ & $22.2 \pm 1.4^{\mathrm{b}}$ & $28.1 \pm 3.6^{a}$ & $13.3 \pm 1.0^{c, d}$ & $9.3 \pm 0.8^{d}$ & $18.3 \pm 1.0^{\mathrm{b}, \mathrm{c}}$ & $12.8 \pm 1.4^{\mathrm{d}}$ \\
\hline Ca 60193 & $9.0 \pm 1.9^{e}$ & $13.4 \pm 1.4^{\mathrm{b}, \mathrm{c}, \mathrm{d}}$ & $16.2 \pm 0.8^{b}$ & $20.6 \pm 2.7^{a}$ & $11.5 \pm 0.3^{c, d, e}$ & $8.2 \pm 0.7^{e}$ & $13.7 \pm 1.2^{\mathrm{b}, \mathrm{c}}$ & $10.1 \pm 0.8^{\mathrm{d}, \mathrm{e}}$ \\
\hline
\end{tabular}

${ }^{1}$ Ala, Alternanthera; Ana, Anadenanthera; Cna, Cocos nucifera; Mca, Mimosa caesalpiniaefolia; Mya, Myrcia; MsaSC, Mimosa scabrella from Santa Catarina; MsaRN, Mimosa scabrella from Rio Grande do Norte; MsaMT, Mimosa scabrella from Mato Grosso.

${ }^{2}$ Sp: Streptococcus pyogenes; Sa: Staphylococcus aureus; Ec: Escherichia coli; K: Klebsiella; Ca: Candida albicans.

${ }^{3} \mathrm{MIC}$, minimum inhibitory concentration (the lowest concentration that inhibited visible growth of microorganisms).

Values correspond to the average \pm standard deviation of three replicates. Averages followed by the same letter are not significantly different $(p>.05)$.

observed by Arruda (2013) (133-576 $\mu \mathrm{mol}$ TE/g) and De-Melo et al. (2016) (310.1-559.3 $\mu \mathrm{mol} \mathrm{TE} / \mathrm{g})$ in samples from Brazil. All the results from using the ORAC method were above those for fruits in natura, such as strawberries $(43.0 \mu \mathrm{mol} \mathrm{TE} / \mathrm{g})$, apples $(30.5 \mu \mathrm{mol} \mathrm{TE} / \mathrm{g})$, blueberries $(96.2 \mu \mathrm{mol} \mathrm{TE} / \mathrm{g})$, and cranberries (90.9 $\mu \mathrm{mol} \mathrm{TE} / \mathrm{g})$ (USDA, 2010).

Although the Mya sample stood out due to its capacity to inhibit yeast, Msa and, especially, MsaSC bee pollen generally stood out for their capacity to inhibit bacterial growth. Arruda (2013), when evaluating Brazilian samples, observed MIC of $1.0-7.3 \mathrm{mg} / \mathrm{mL}$ for Staphylococcus epidermides and S. aureus, $1.9-8.0 \mathrm{mg} / \mathrm{mL}$ for $E$. coli, and $7.8-$ $29.0 \mathrm{mg} / \mathrm{mL}$ for C. albicans. Pascoal, Rodrigues, Teixeira, Féas, and Estevinho (2014), who tested eight bee pollen samples produced in Portugal for the inhibition of S. aureus, Pseudomonas aeruginosa, E. coli, and Candida glabrata, found that $S$. aureus strains were more sensitive, with MIC values between 1.81 and $4.28 \mathrm{mg} / \mathrm{mL}$. For the other microorganisms, the authors observed 3.71-6.96 mg/mL ( $P$. aeruginosa), 4.08$9.42 \mathrm{mg} / \mathrm{mL}$ (E. coli), and $16.00-33.92 \mathrm{mg} / \mathrm{mL}$ (C. glabrata). The results of the present study corroborate these observations, since the Grampositive bacteria have greater sensitivity than Gram-negative bacteria, which could be explained by the greater complexity of the cell wall of the latter.

The phenolic compounds are described as the main bioactive agents in bee pollen (Carpes et al., 2008), and as there is variation in the phenolic profile depending on botanical origin and processing conditions, it is to be expected that the antimicrobial capacity, as well as the antioxidant capacity, would undergo the same influences. It is necessary to consider that, though phenolic compounds are considered important, other substances present, such as spermidine derivatives, also have antimicrobial capacity (Bassard, Ullmann, Bernier, \& WerckReichhart, 2010; Mihajlovic, Radosavljevic, Burazer, Smiljanic, \& Velickovic, 2015).

In terms of M. scabrella monofloral bee pollen produced in Brazil, as was seen for the physicochemical parameters, it does not seem possible to establish a biological potential profile, given that there was significant variation in the parameters among the three samples, according to a harvesting site.

\section{3 | Phenolic profile by HPLC-MS}

The results obtained by HPLC-MS for the eight bee pollen samples from seven Brazilian states, as well as the proposed identification for the observed compounds, are presented in Table 5. Flavonoid glycosides predominated, mainly the 3-O-glycosides of quercetin, kaempferol, and isorhamnetin. Negri et al. (2011) also found flavonoid glycosides in bee pollen from Pindamonhagaba, Brazil. In plant extracts, there is a great variety of bioactive substances, and flavonoids are frequently found in the form of $\mathrm{O}$ - or $\mathrm{C}$-glycosides, with sugar units connected directly to the hydroxyl or to one of the carbon atoms of the aglycone.

The pinobanksin derivative was found in the seven bee pollens, that is, it was identified not only in the Ana sample. It is a dihydroflavonol with antibacterial potential that had already been observed in honey and propolis (Falcão et al., 2013; Keckes et al., 2013). The 4methylsulfonylbutyl glucosinolate (glucoraphanin), found in three samples (Ala, Mca, and MsaSC), is part of the group of glucosinolates 


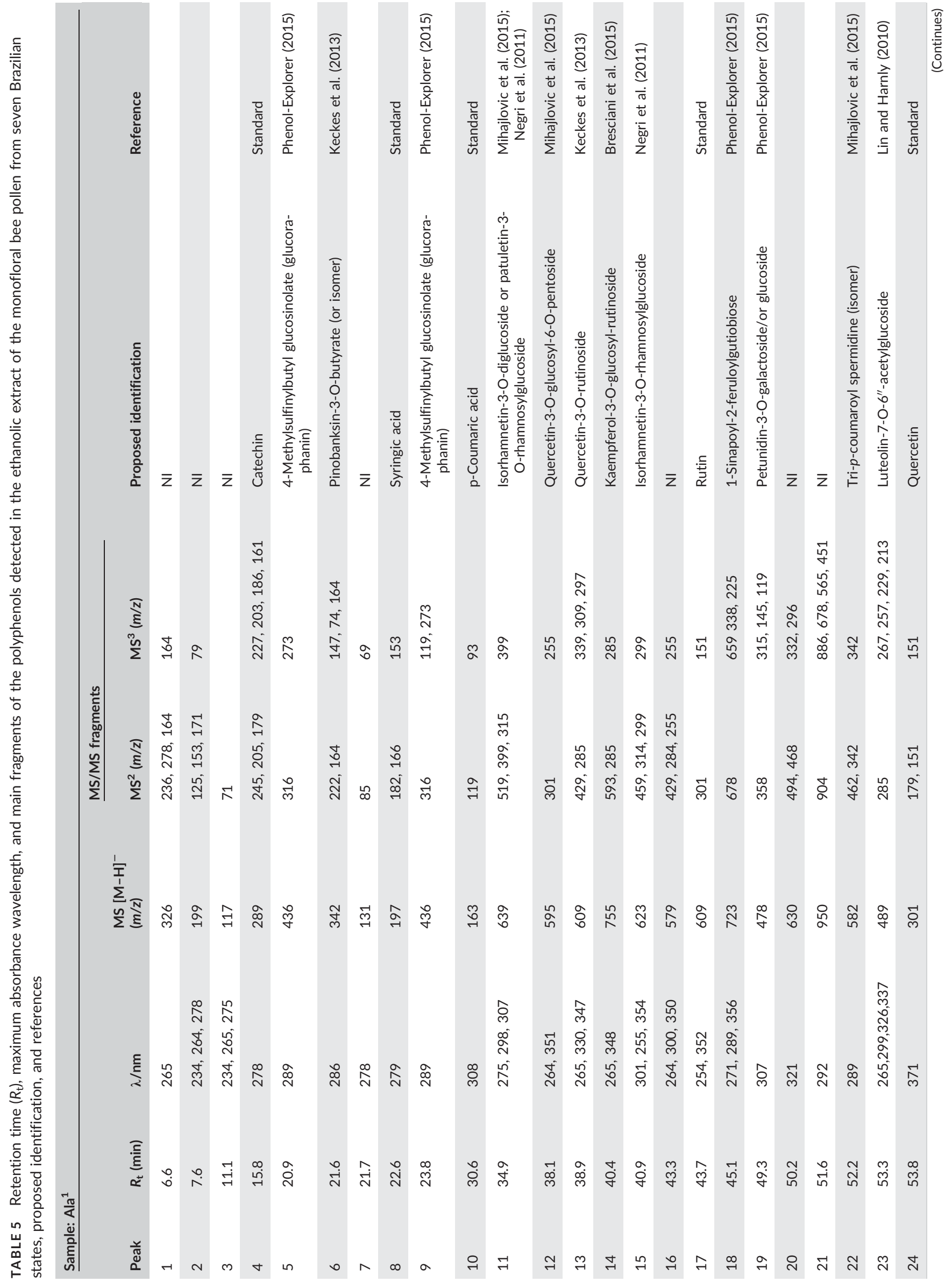




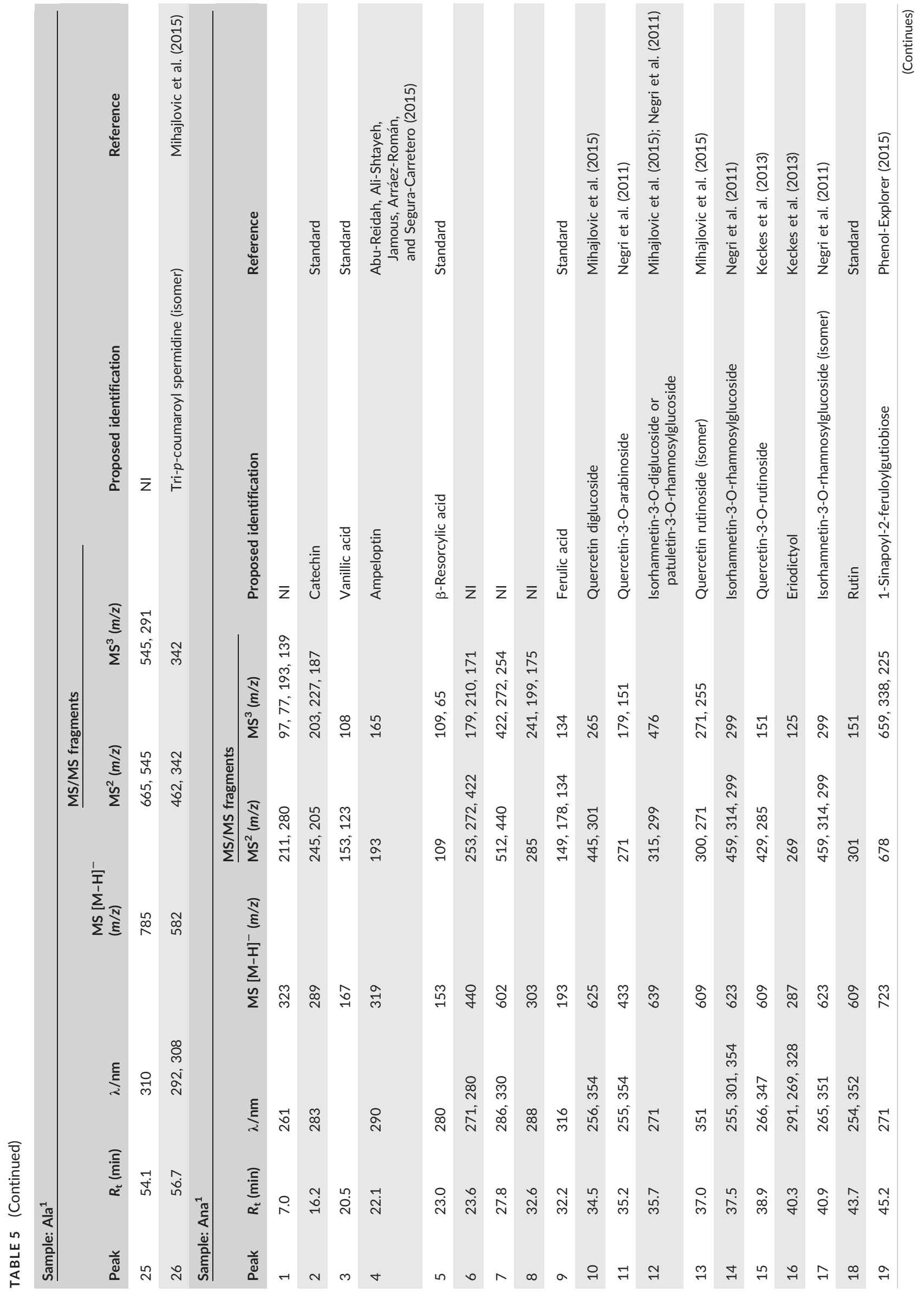




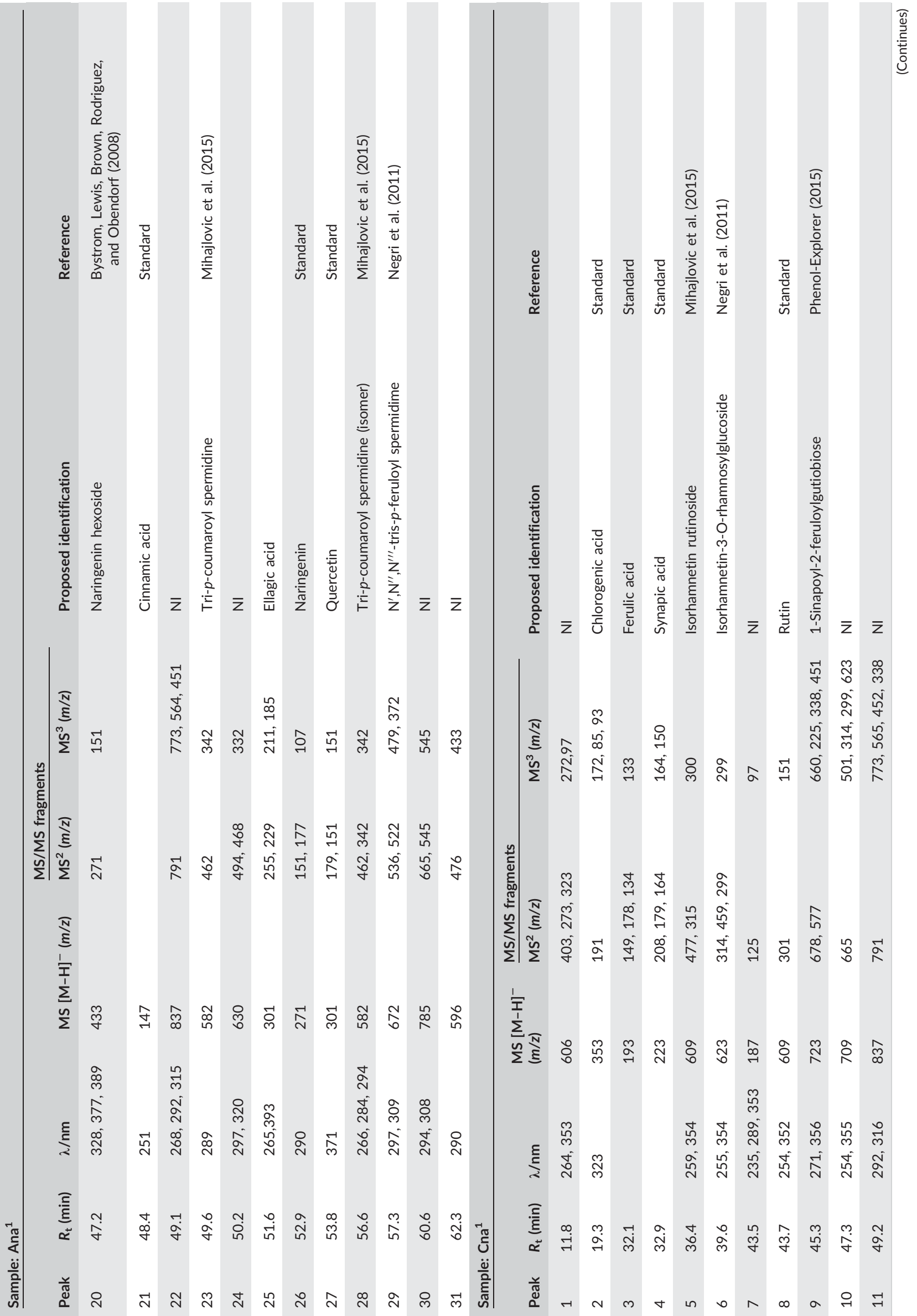




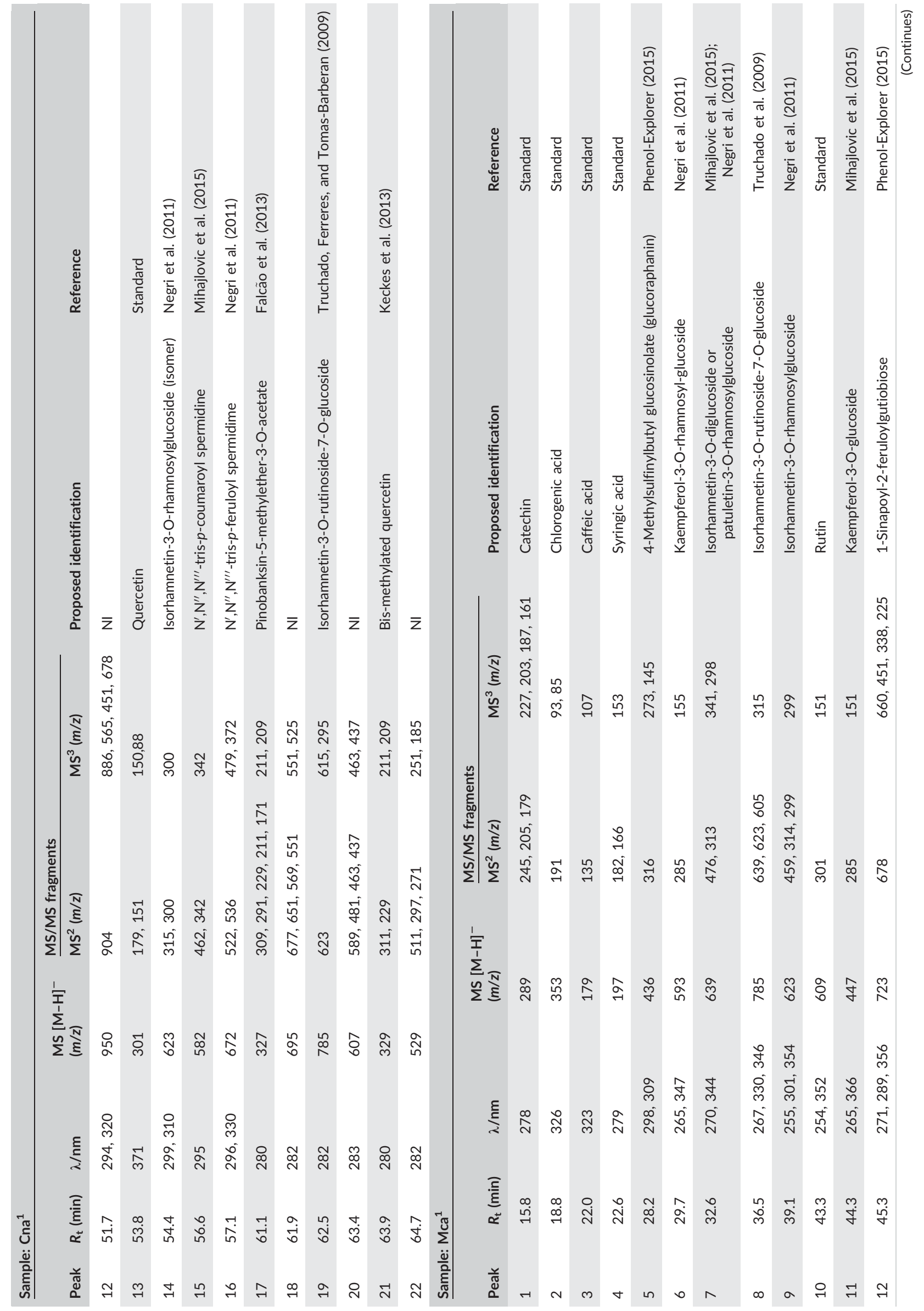



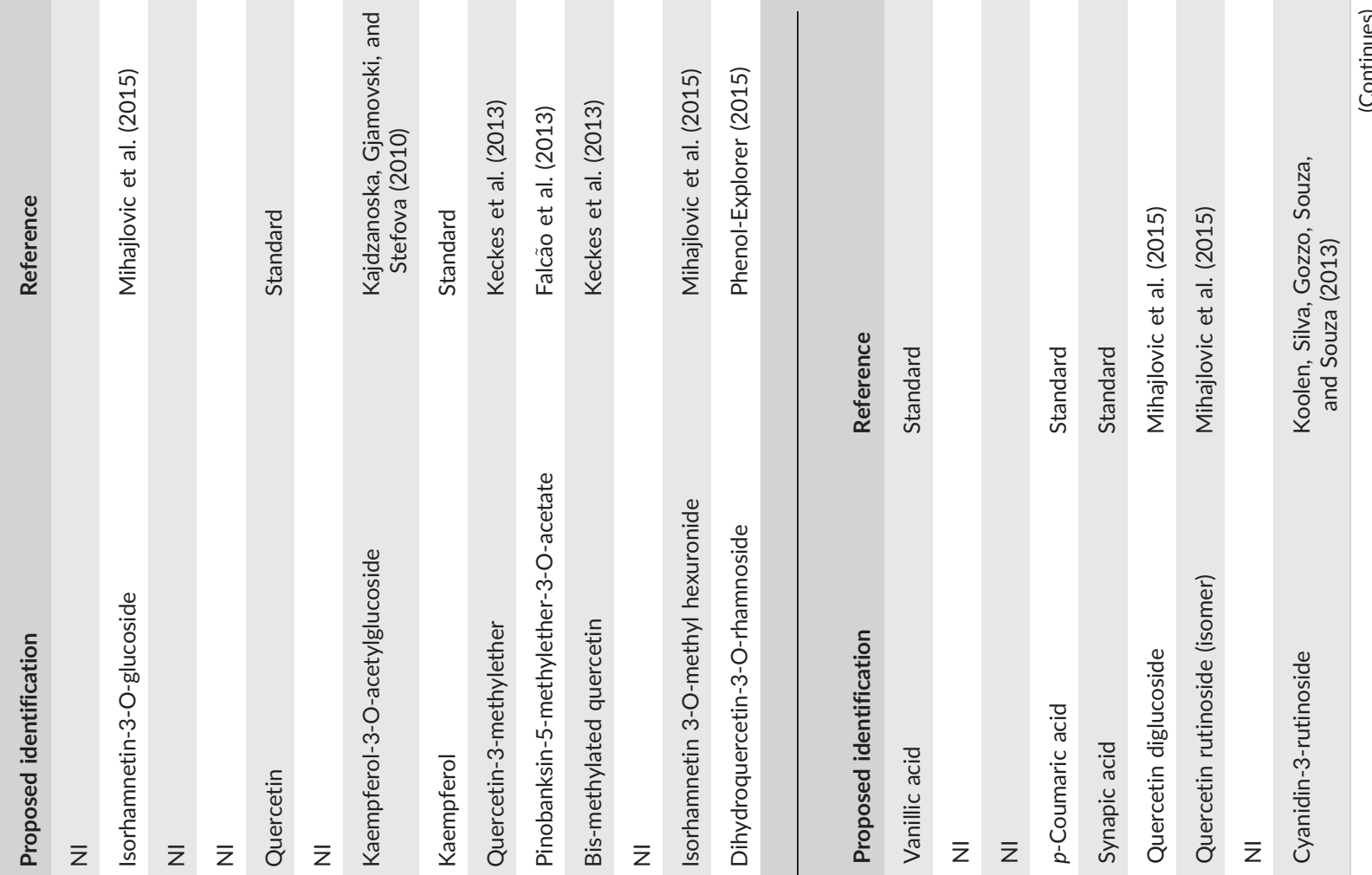

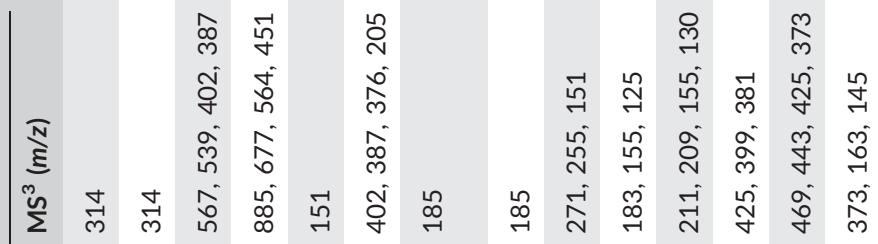

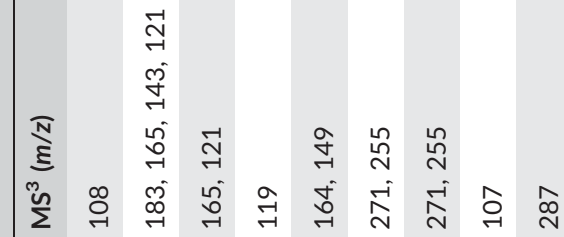

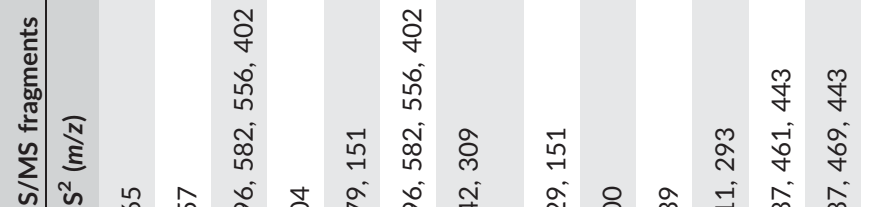

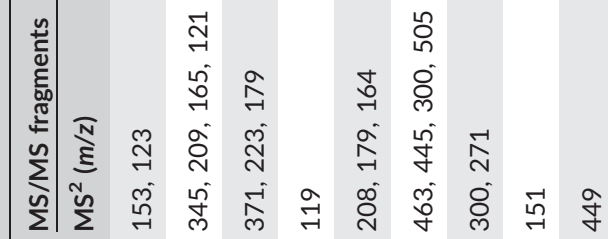

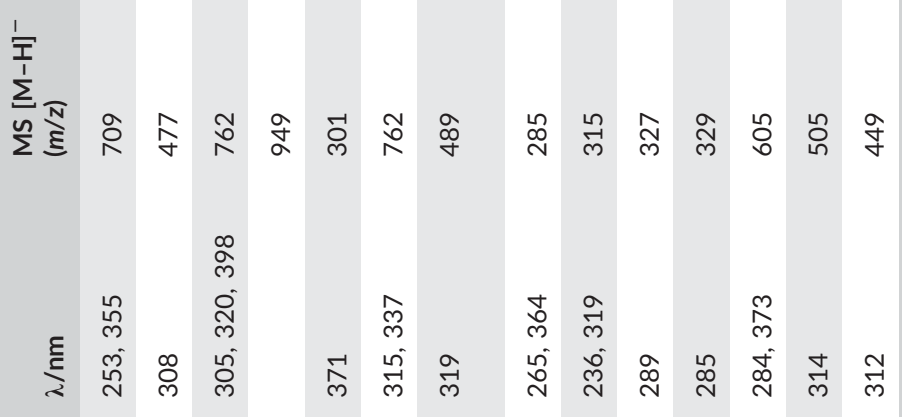

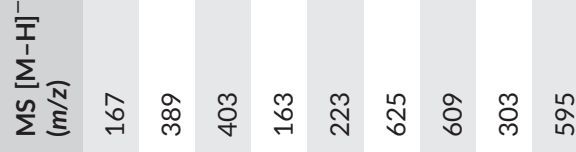



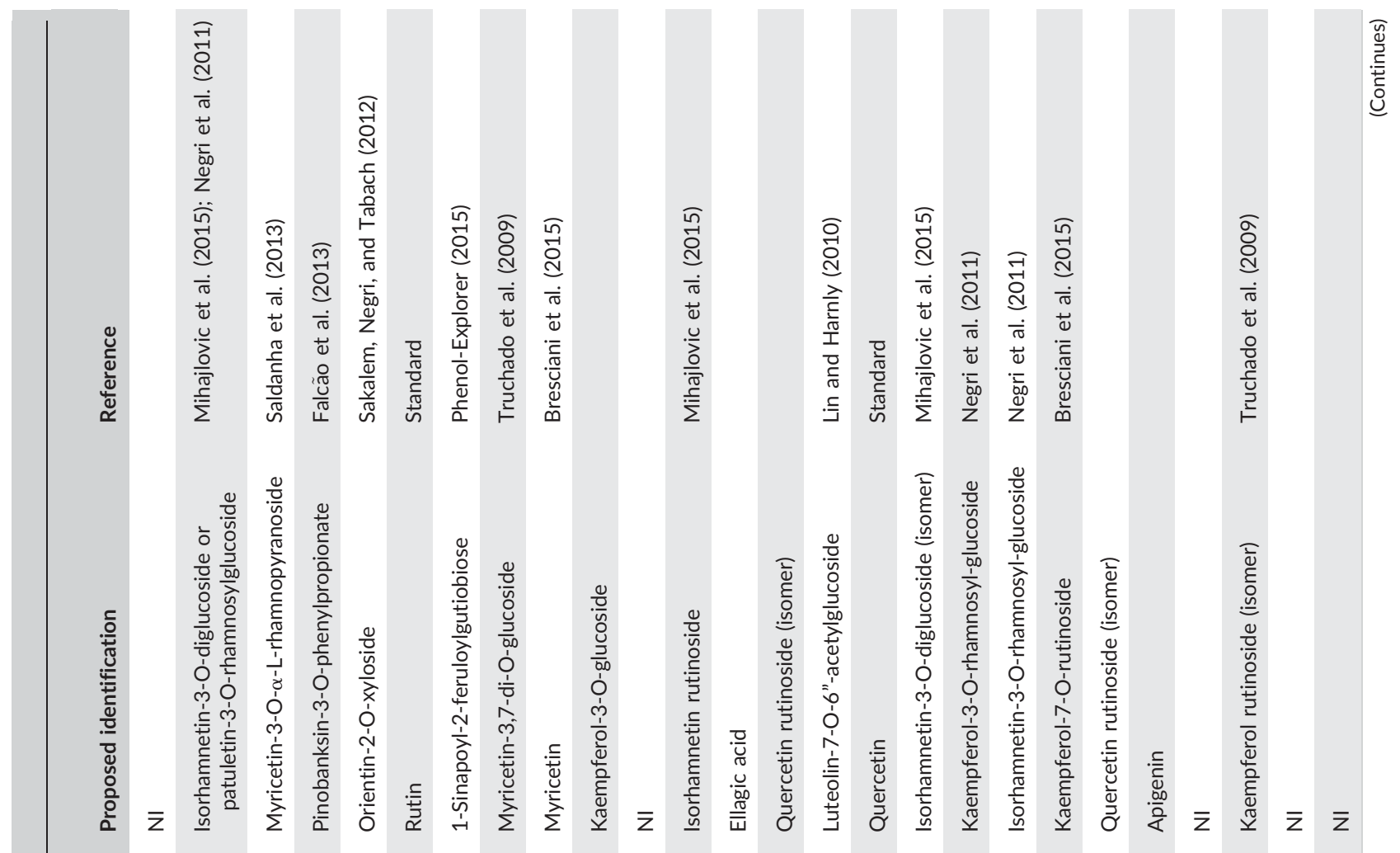

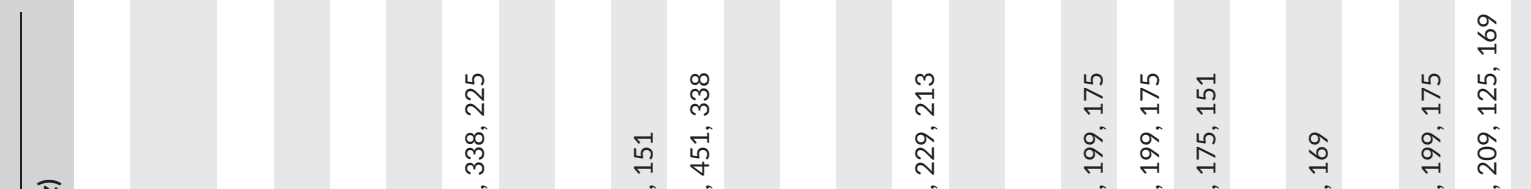

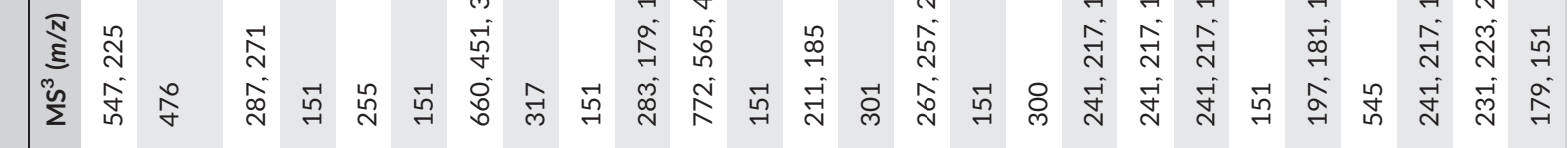

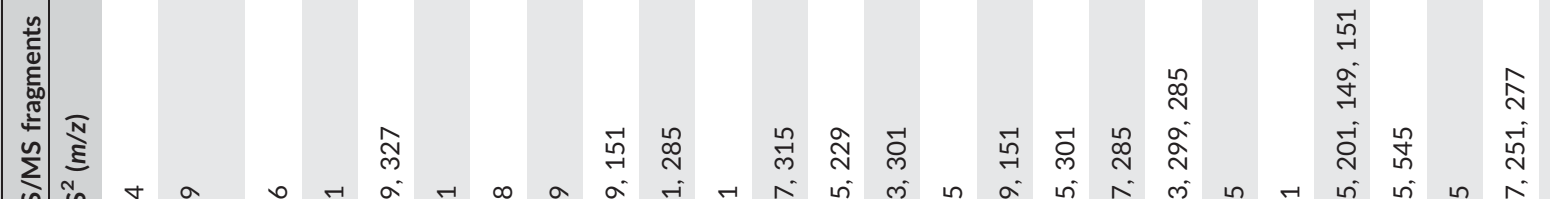

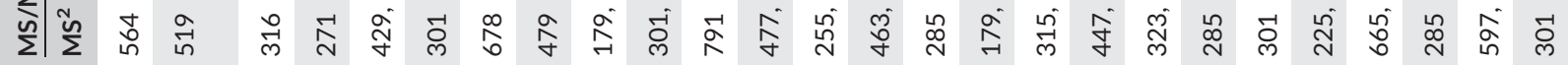

$\frac{1}{1}$

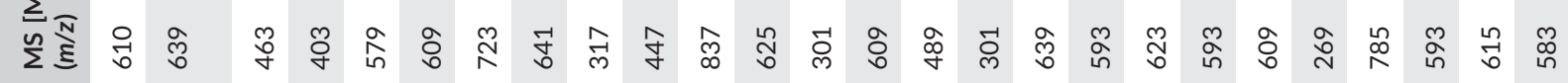

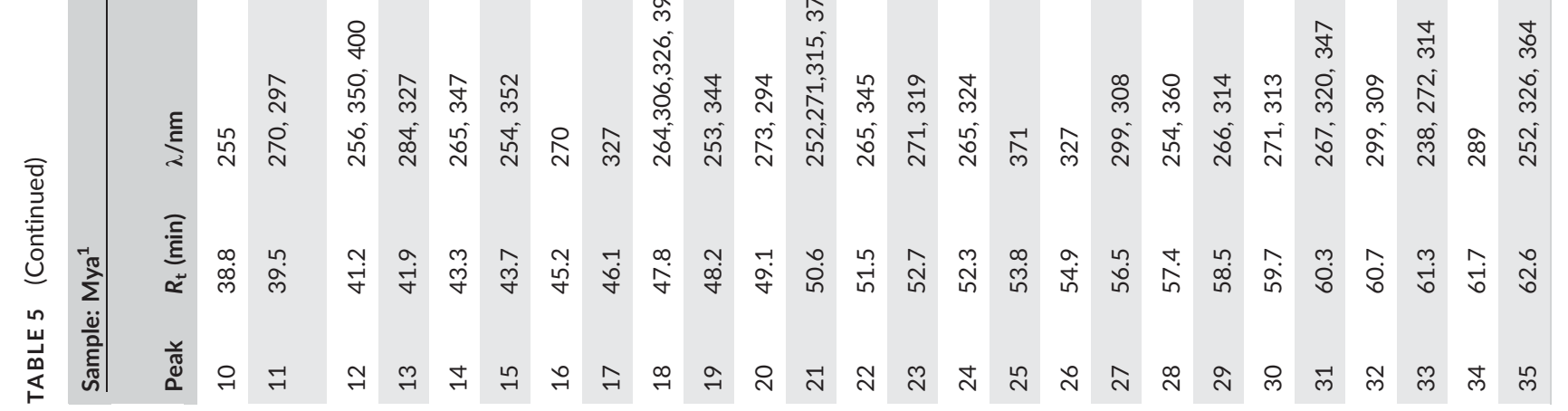

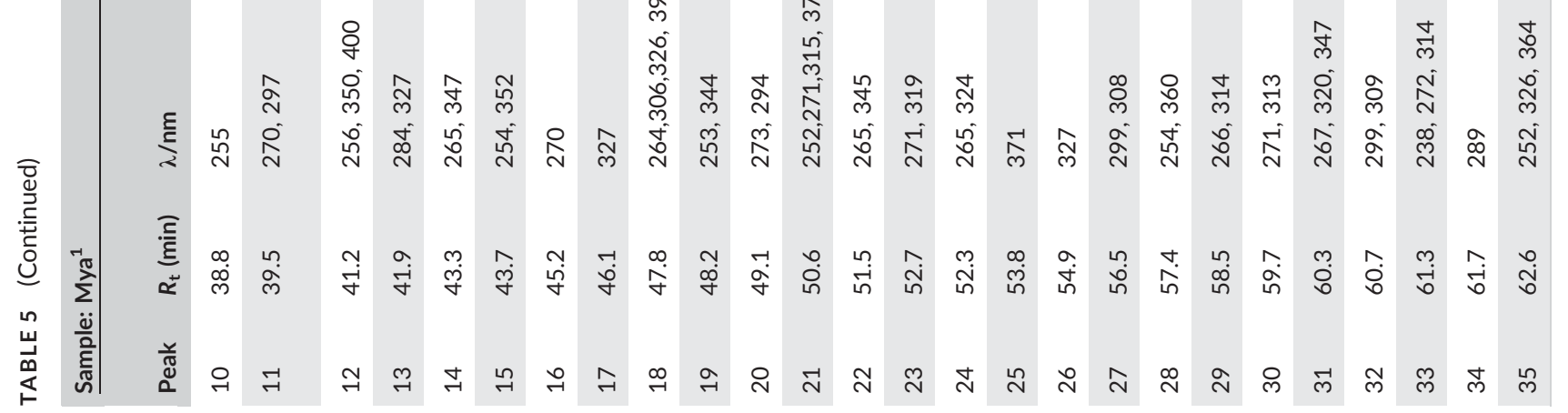

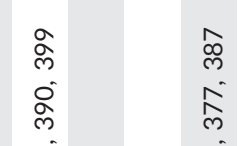




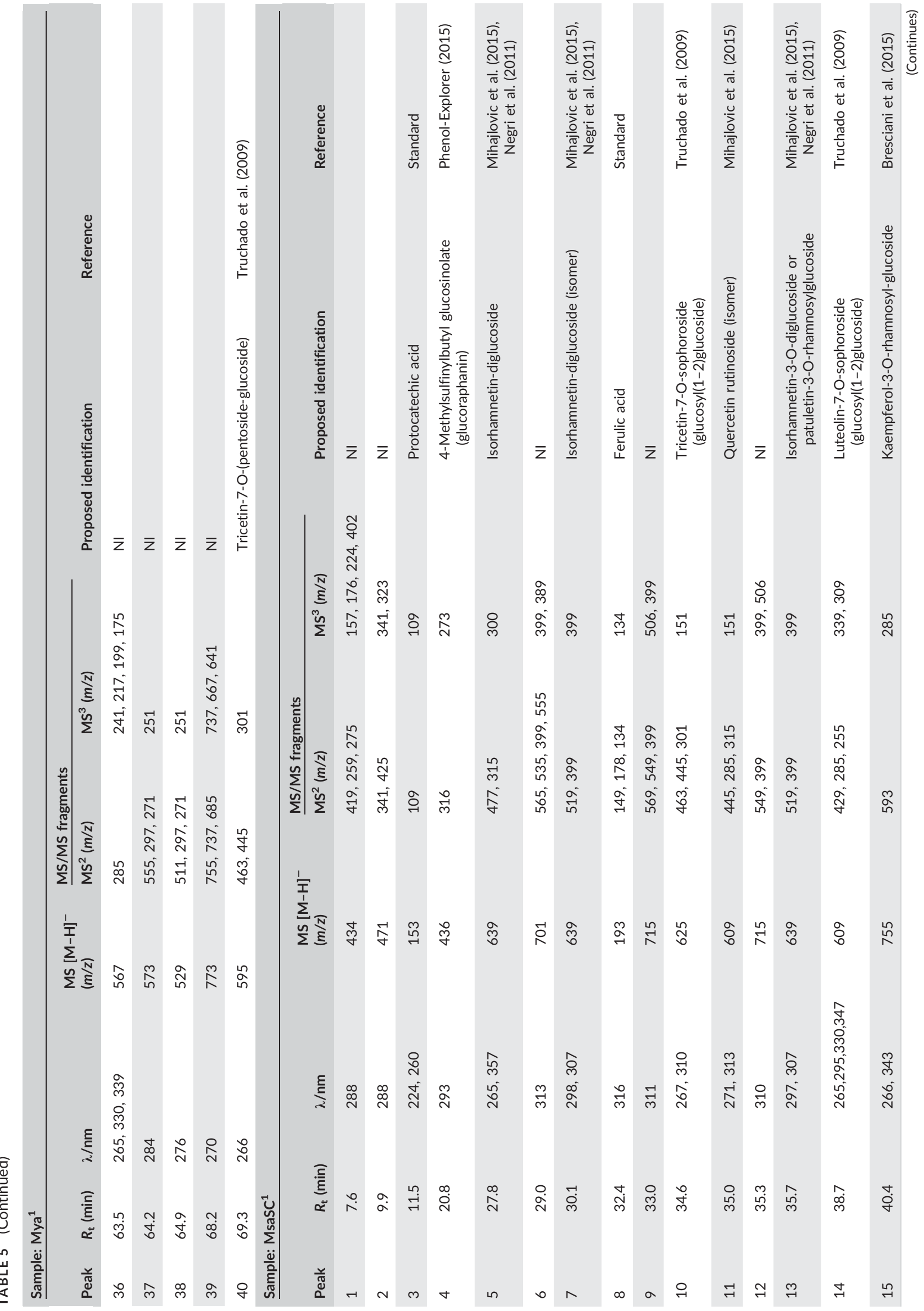




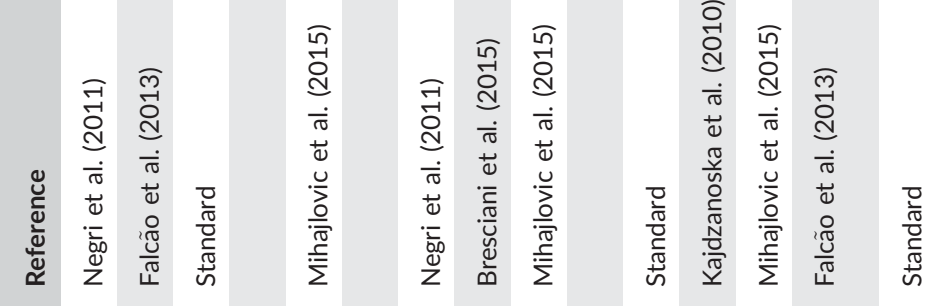
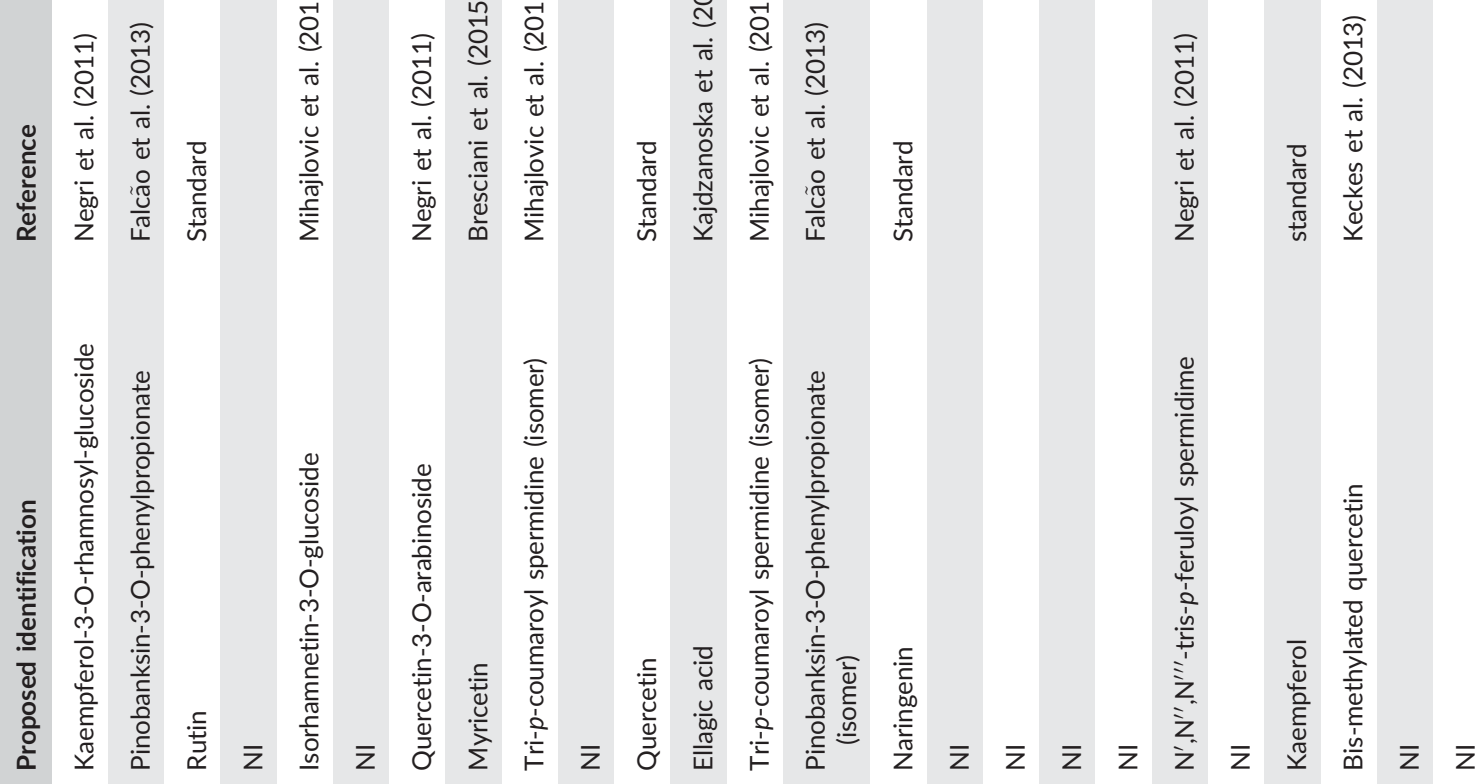

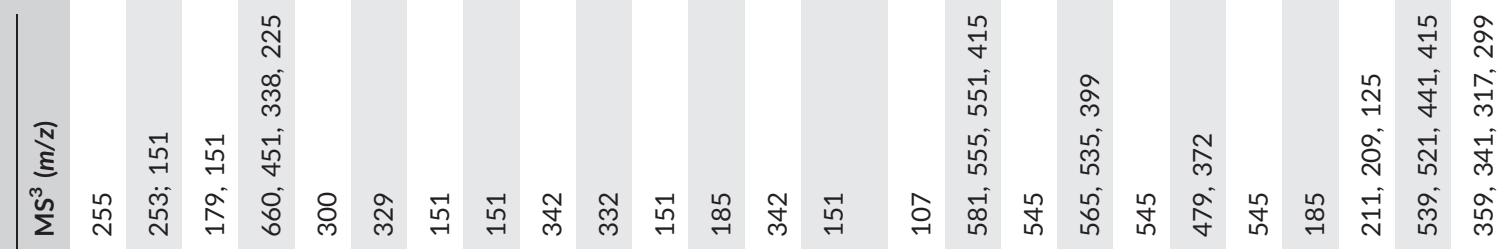

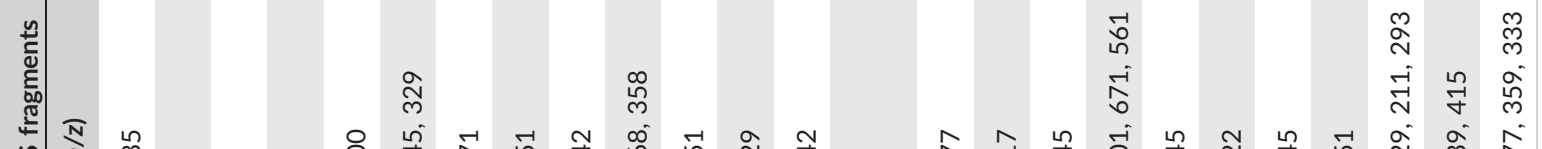

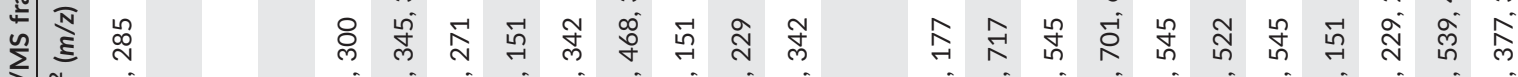

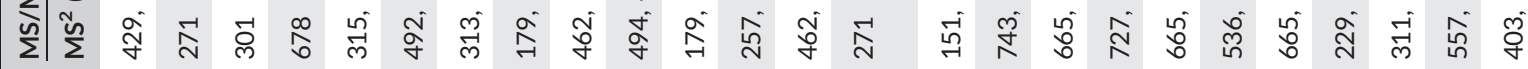

$\sum_{\substack{\text { I } \\ \Sigma}}^{\frac{1}{\mathrm{~N}}}$

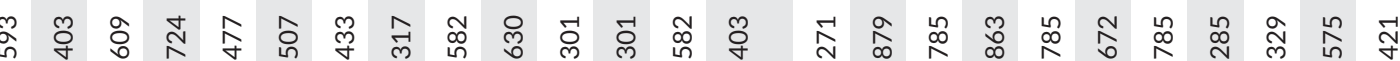

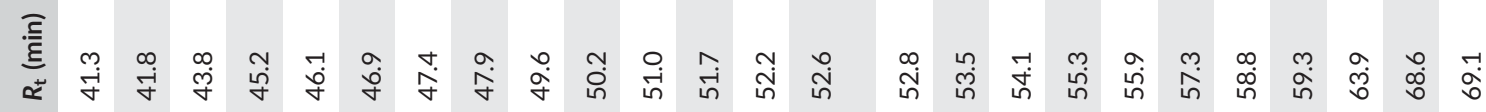

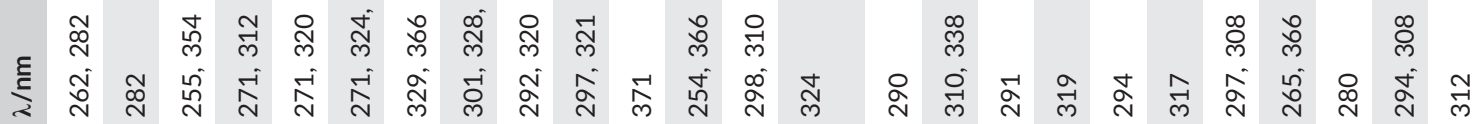

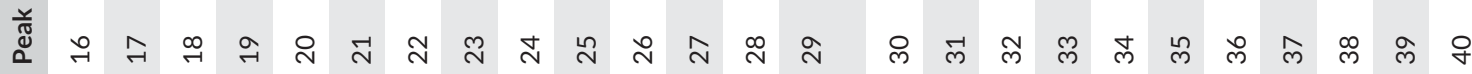



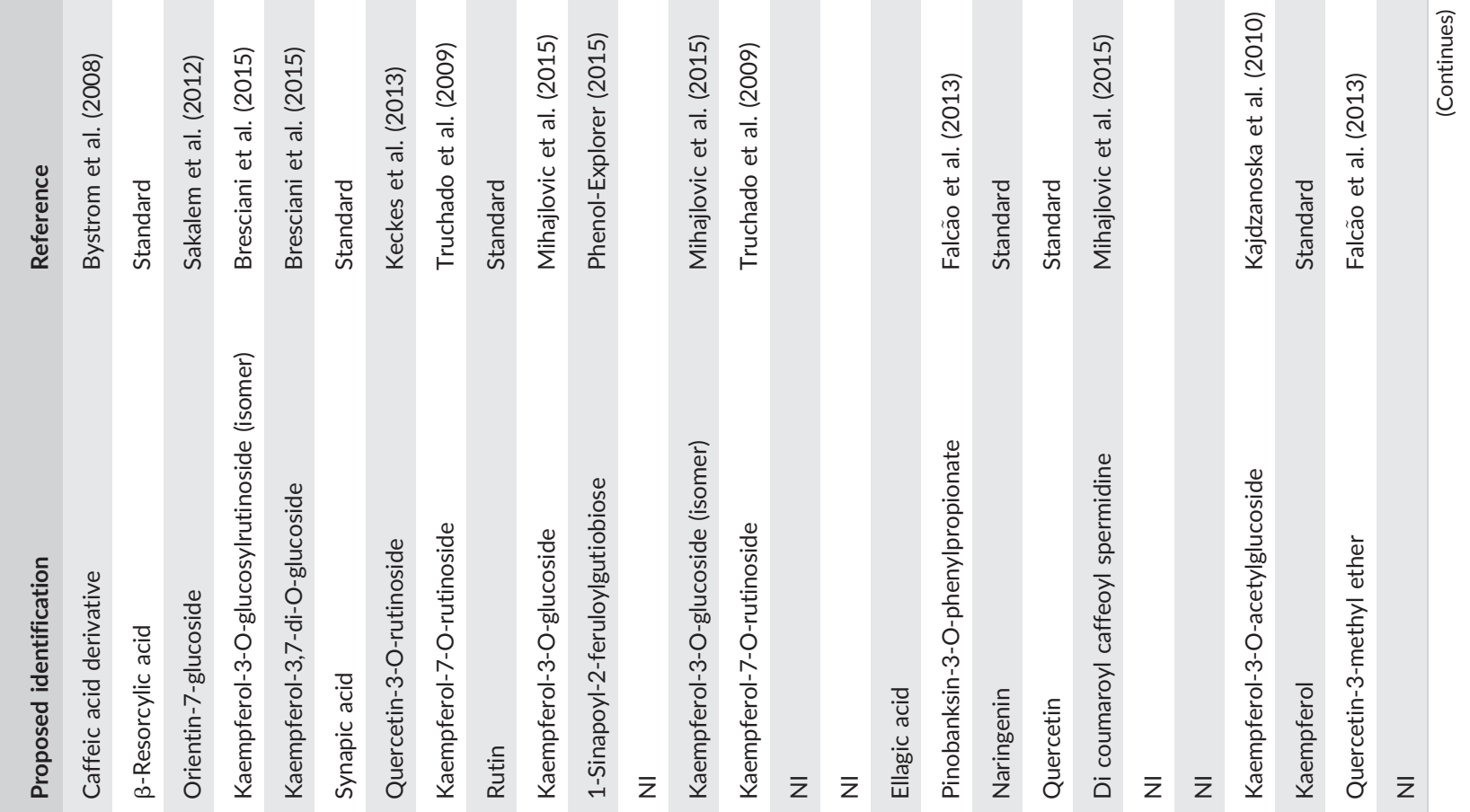

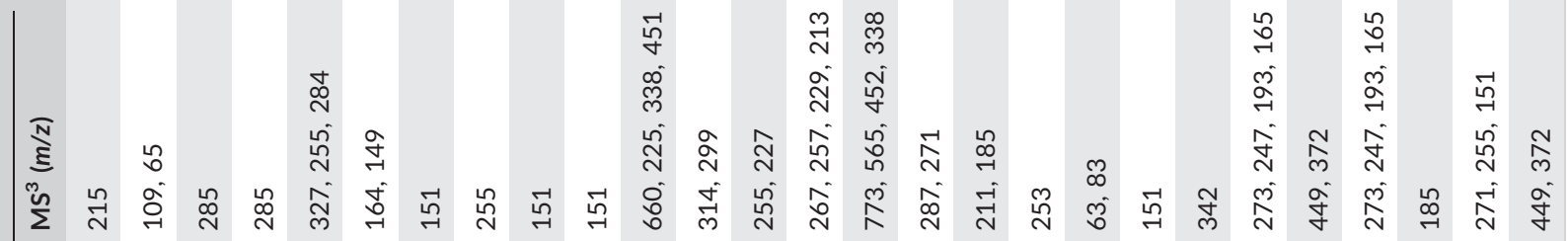

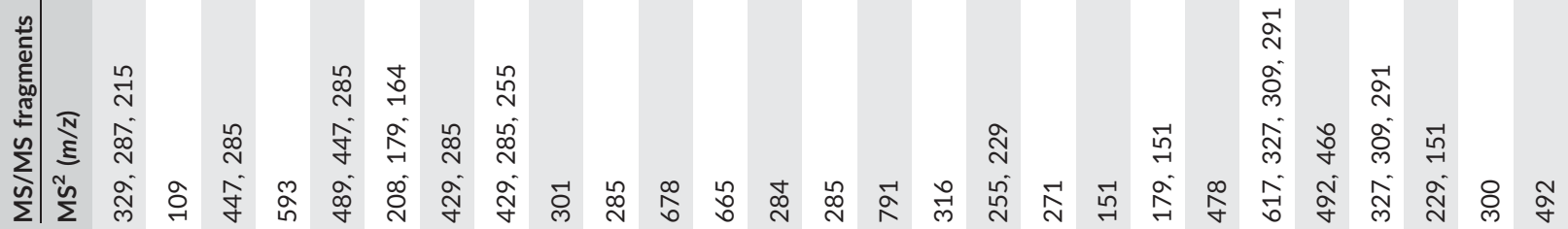

$\sum^{\frac{1}{1}}$

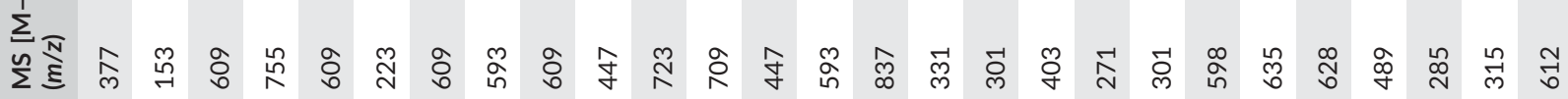

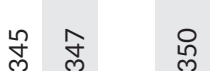

ले

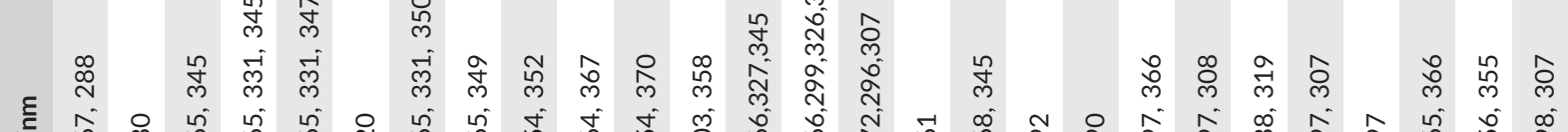

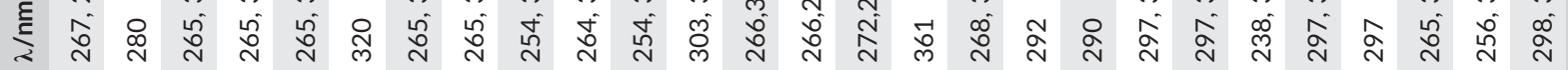

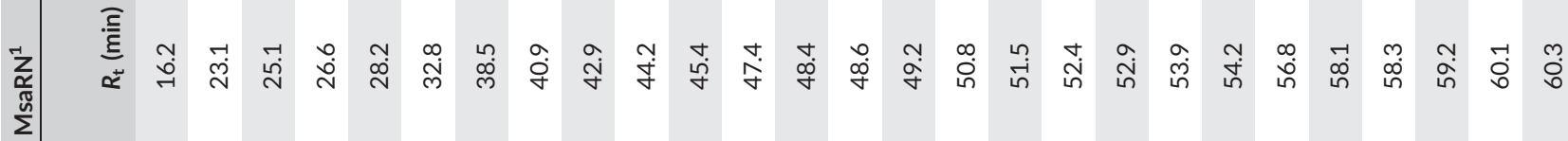

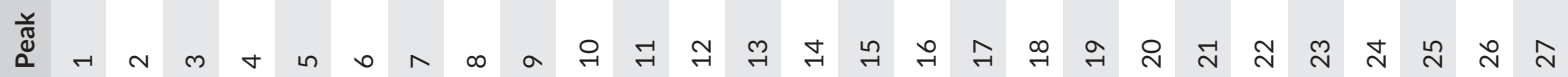




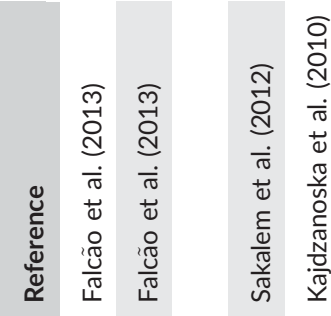

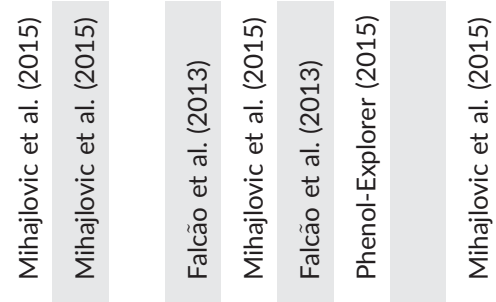

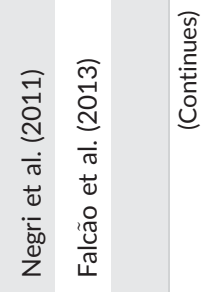
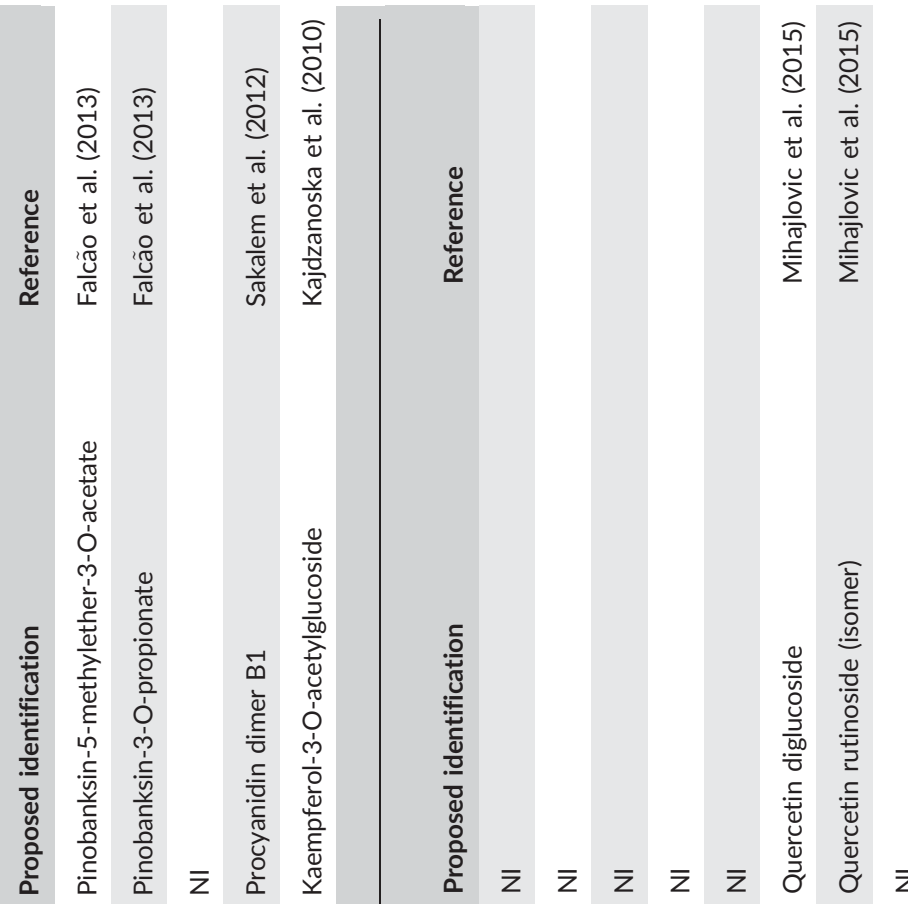

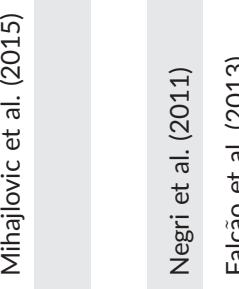

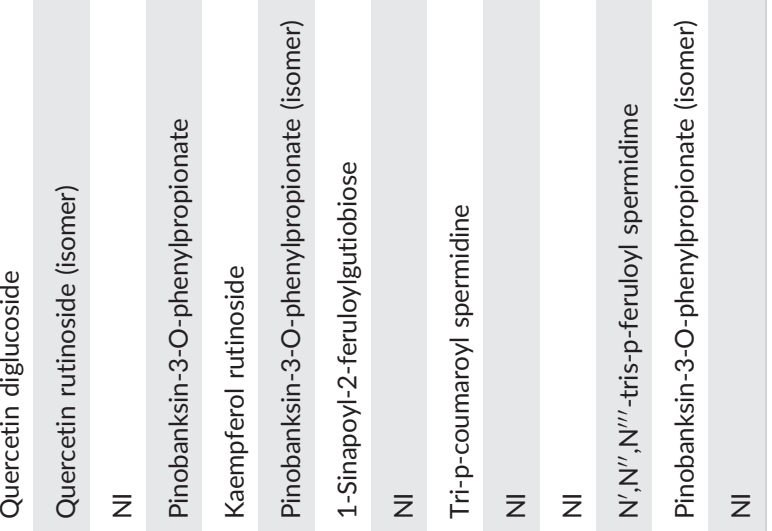

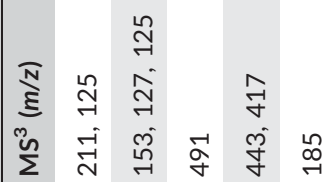

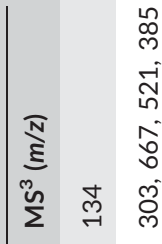

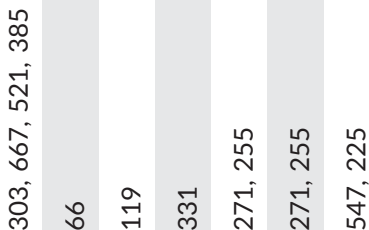

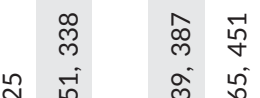

o

$\sin$

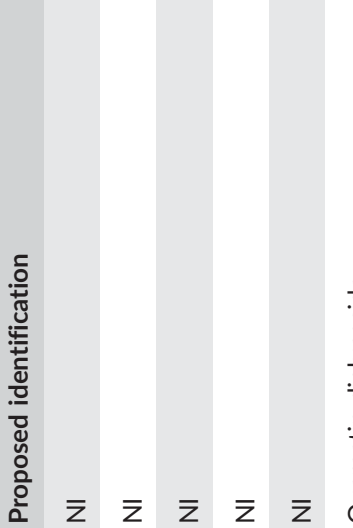

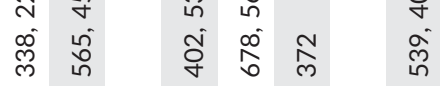

ง

जु

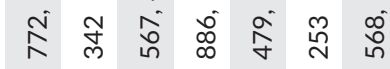

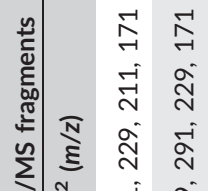

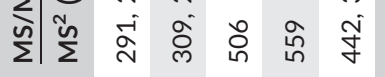

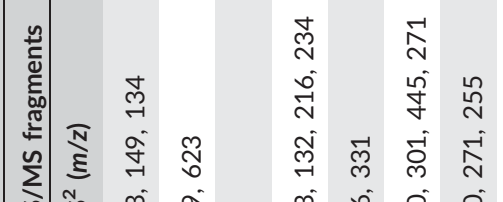

商管

$\sum_{\sum^{n}}^{\frac{1}{T}}$

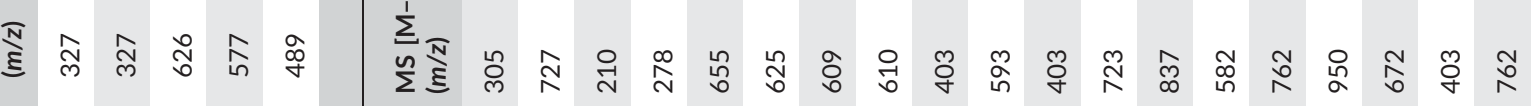

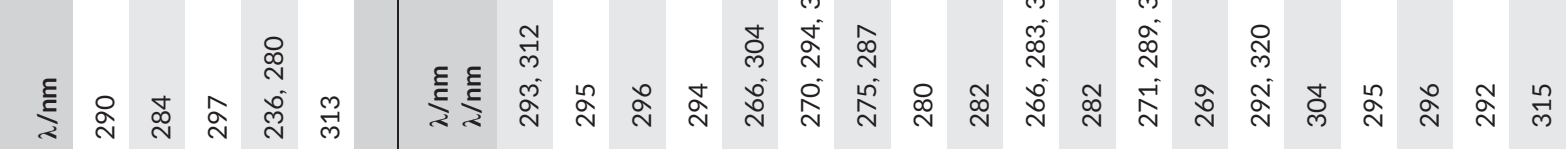

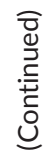

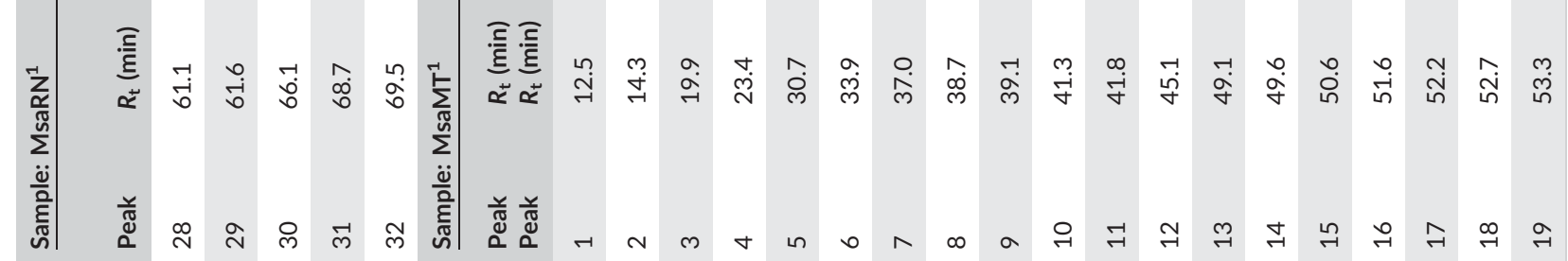




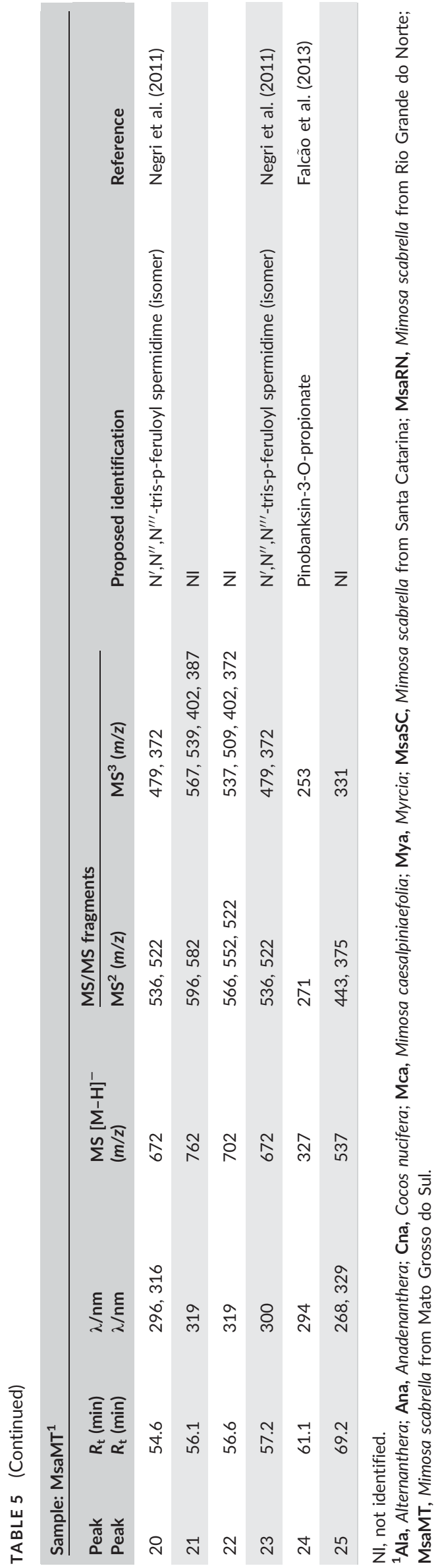

whose compounds occur mainly in plants from the Brassicaceae but also in other angiosperms. Based on the literature reviewed, this was the first time that this substance was identified in bee pollen.

In the MS spectra of the Ala sample, 26 peaks were observed, of which 18 were identified: 5 confirmed using standards available in the laboratory (Table 2), and the remainder based on the literature. The compounds identified by comparison with the standards were catechin $(0.73 \pm 0.08 \mathrm{mg} / 100 \mathrm{~g})$, syringic acid ( $4.81 \pm 0.05 \mathrm{mg} / 100 \mathrm{~g}), p$-coumaric acid $(0.47 \pm 0.02 \mathrm{mg} / 100 \mathrm{~g})$, rutin $(6.65 \pm 0.05 \mathrm{mg} / 100 \mathrm{~g})$, and quercetin $(1.92 \pm 0.02 \mathrm{mg} / 100 \mathrm{~g})$

In the Ala sample, of the compounds identified based on the literature, a glycosylated anthocyanin (petunidine-3-O-galactoside, retention time: $49.3 \mathrm{~min}$ ) and a spermidine derivative (tri- $p$-coumaryl spermidine, retention time: $56.7 \mathrm{~min}$ ) seem to be the most prominent. Petunidine3-O-galactoside results from the substitution of a hydroxyl of the aglycone by a unit of galactose. Petunidin derivatives had been previously identified in red wine, but, from what we understand, the present study was the first to report the presence of these compounds in bee pollen. The tri-p-coumaryl-spermidine is a conjunction of polyamine with phenolic compounds, which are part of the group of bioactive substances with antimicrobial potential (Bassard et al., 2010). The occurrence of spermidine derivatives was reported in Ambrosia artemisiifolia L. pollen from Belgrade, Serbia (Mihajlovic et al., 2015).

In the analysis of the Ana sample, 31 peaks were observed, with 23 being identified based on the literature and from available information of the standards. The compounds identified based on the standards were also quantified: $0.69 \pm 0.03 \mathrm{mg}$ of catechin/100 g, $12.54 \pm$ $0.12 \mathrm{mg}$ of $\beta$-resorcylic acid/100 g, $1.04 \pm 0.01 \mathrm{mg}$ of ferulic acid/ $100 \mathrm{~g}, 3.66 \pm 0.14 \mathrm{mg}$ of rutin/100 g, $13.05 \pm 0.08 \mathrm{mg}$ of cinnamic $\mathrm{acid} / 100 \mathrm{~g}, 7.42 \pm 0.15 \mathrm{mg}$ of quercetin $/ 100 \mathrm{~g}$, and $4.57 \pm 0.17 \mathrm{mg}$ of naringenin/100 g. Naringenin is a compound with antioxidant activity commonly found in grapefruit juice; however, Leblanc, Davis, Boue, Delucca, and Deeby (2009) also identified this substance in bee pollen from the Sonoran Desert, North of Tucson, AZ. In the present study, the compound was also observed in the MsaSC and MsaRN samples.

Considering the intensity of the peaks, the two spermidine derivatives stand out as the main compounds in the Ana bee pollen: tri- $p$ coumaryl-spermidine (retention time: $56.6 \mathrm{~min}$ ) and $\mathrm{N}^{\prime}, \mathrm{N}^{\prime \prime}, \mathrm{N}^{\prime \prime}$-tris- $p$-feruloyl-spermidine (retention time: $57.3 \mathrm{~min}$ ). The longer retention time for the latter indicates a lower polarity in relation to the others, which coincides with the observations of Negri et al. (2011) in bee pollen samples. The authors attribute the lower polarity of this substance to the presence of a methoxyl group in the feruloyl moiety. The ampeloptin and eriodictyol compounds are only found in the Ana bee pollen. Ampeloptin (or dihydromyricetin) is used in Chinese medicine as an anti-inflammatory agent. Previously, Keckes et al. (2013) suggested that eriodictiol and quercetin can be used as markers for sunflower honey produced in Serbia.

Amongst the spectra generated, that of the Cna bee pollen had the lowest number of peaks (22), of which 14 were identified. This sample had the lowest antioxidant capacity and low antimicrobial capacity against bacteria, as previously mentioned, which could be related to the lower number and/or types of compounds present. An 
isorhamnetin (isorhamnetin-3-O-rhamnosyl-glycoside) glycoside was the main compound, which had already been identified in bee pollen (Negri et al., 2011). Other authors also identified the presence of flavonoid-O-glycoside in honey, with the type and amount correlated with the botanical origin of the samples. Five compounds were confirmed by comparison with the standards, and the following amounts were found: chlorogenic acid $(4.85 \pm 0.12 \mathrm{mg} / 100 \mathrm{~g})$, ferulic acid $(0.71 \pm 0.02 \mathrm{mg} / 100 \mathrm{~g})$, synapic acid $(0.29 \pm 0.03 \mathrm{mg} / 100 \mathrm{~g})$, rutin $(4.78 \pm 0.10 \mathrm{mg} / 100 \mathrm{~g})$, and quercetin (1.86 $\pm 0.01 \mathrm{mg} / 100 \mathrm{~g})$.

Of the 26 peaks observed in the Mca sample, 21 were identified. This was one of the two samples in which the main compound (retention time: $56.1 \mathrm{~min}$ ), the compound that was also found in the MsaMT sample, was not identified. The second peak of highest intensity corresponds to the isorhamnetin-3-O-glycoside. Seven compounds were confirmed and quantified using the standard data: $0.75 \pm 0.05 \mathrm{mg}$ of catechin/100 g, $4.53 \pm 0.19 \mathrm{mg}$ of chlorogenic acid/100 g, $0.15 \pm$ $0.01 \mathrm{mg}$ of caffeic acid/100 g, $5.36 \pm 0.24 \mathrm{mg}$ of syringic acid/100 g, $8.39 \pm 0.16 \mathrm{mg}$ of rutin/100 g, $2.91 \pm 0.06 \mathrm{mg}$ of quercetin $/ 100 \mathrm{~g}$, and $7.40 \pm 0.45 \mathrm{mg}$ of kaempferol/100 g.

In the Mya bee pollen, 40 peaks were detected, with 28 being identified. The main compounds were suggested to be myricetin (retention time: $47.8 \mathrm{~min}$ ) and ellagic acid (retention time: $51.5 \mathrm{~min}$ ). Myricetin has antioxidant potential and, depending on the concentration and on the conditions of the medium, can act as a pro-oxidant. Ellagic acid is a dimeric derivative of gallic acid with anti-inflammatory (Bae et al. 2010) and antioxidant (Festa et al., 2001) activity. Saldanha, Vilegas, and Dokkedal (2013) analyzed extracts from Mycia bella, a species from the Myrcia genus common in areas of the Cerrado, and identified, as the present study, glycosides of myricetin, quercetin, and kaempferol. Of the 40 compounds detected, 4 corresponded to standards that were quantified in the Mya bee pollen for HPLC-PDA: vanillic acid $(6.06 \pm 0.08 \mathrm{mg} / 100 \mathrm{~g}), p$-coumaric acid $(6.68 \pm 0.02 \mathrm{mg} / 100 \mathrm{~g})$, rutin $(3.98 \pm 0.01 \mathrm{mg} / 100 \mathrm{~g})$, and quercetin $(67.91 \pm 0.25 \mathrm{mg} / 100 \mathrm{~g})$. This was the highest level of quercetin observed amongst the samples. The highest antioxidant capacity for both methods was also observed in the Mya bee pollen.

Cyanidin-3-rutinoside and apigenin compounds were only identified in the Mya bee pollen sample. The first is a polyphenol from the anthocyanin group with the potential to assist in the prevention of degenerative diseases and has already been identified in Euterpe oleracea (açaí) collected in the Pará state, Brazil (Gouvêa et al., 2012). Apigenin is a flavonoid from the flavonas class, found in fruits and vegetables, with anti-inflammatory, antioxidant, and antitumor activity (Shukla \& Gupta, 2010).

Each of the three Msa samples presents a singular phenolic profile. This variability can be related to genotypic and agronomic differences; climatic conditions such as temperature, water stress, and light intensity; as well as soil conditions, which can influence the phenolic composition of these plants. In the MsaSC bee pollen, a larger number of peaks were observed (40), and, though the main compound was not identified (retention time: $53.6 \mathrm{~min}$ ), the other 25 were. The determined phenolic content based on the standards using HPLC-PDA varied from $1.50 \pm 0.01$ to $46.80 \pm 2.57 \mathrm{mg} / 100 \mathrm{~g}$, with the quantified compounds being protocatechic acid (1.50 $\pm 0.01 \mathrm{mg} / 100 \mathrm{~g})$, rutin (46.80 $\pm 2.57 \mathrm{mg} / 100 \mathrm{~g})$, naringenin (18.36 $\pm 1.09 \mathrm{mg} / 100 \mathrm{~g})$, quercetin $(5.97 \pm 0.29 \mathrm{mg} / 100 \mathrm{~g})$, and kaempferol $(5.50 \pm 0.31 \mathrm{mg} / 100 \mathrm{~g})$. It is worth noting that, in this monofloral bee pollen, from what we can tell, two compounds common to plants from the Myrica genus (myricetin and tricetin-7-O-sophoroside[glycosyl(1-2)glycoside]) were identified for the first time.

In the MsaRN sample, 32 peaks were observed in the MS spectra, of which 25 were identified. Kaempferol-3-O-glycoside was the main compound (retention time: $44.2 \mathrm{~min}$ ). Additionally, seven other glycosides of this flavonol were identified. $\beta$-resorcylic acid, synaptic acid, rutin, naringenin, quercetin, and kaempferol were confirmed by comparison with the available standards, and their contents were $9.65 \pm$ $0.12 \mathrm{mg} / 100 \mathrm{~g}, 0.33 \pm 0.03 \mathrm{mg} / 100 \mathrm{~g}, 25.81 \pm 0.31 \mathrm{mg} / 100 \mathrm{~g}$, $10.41 \pm 0.25 \mathrm{mg} / 100 \mathrm{~g}, 5.05 \pm 0.21 \mathrm{mg} / 100 \mathrm{~g}$, and $44.97 \pm 2.88 \mathrm{mg} /$ $100 \mathrm{~g}$, respectively. Procyanidin B1, which was only identified in MsaRN sample, is a substance with antioxidant activity (Amíc \& Lucic, 2010).

In the MsaMT bee pollen, of the 25 observed peaks, 12 were identified, including the main one ( $\mathrm{N}^{\prime}, \mathrm{N}^{\prime \prime}, \mathrm{N}^{\prime \prime}$-tris- $p$-feruloyl-spermidine). Of the three M. scabrella samples, the lowest number of compounds was observed in MsaMT sample, together with the lowest antioxidant capacity for both methods (Table 4). LeBlanc et al. (2009) also identified the lowest antioxidant activity in bee pollen sample with the smallest number of polyphenols. The antimicrobial capacity of the MsaMT sample was intermediary, indicating that this parameter can experience a greater influence from the type of a phenolic compound present in the sample than from the total number of compounds.

\section{4 | CONCLUSIONS}

Monofloral bee pollen from Brazil has a variable composition and a singular profile. Though some researchers have suggested that there is a standard between monofloral samples from the same pollen type, in the present study, it can be seen that this is not the case for M. scabrella bee pollen. Monofloral bee pollen could be a protein source for consumers, especially for those who have a restrictive diet, such as some types of vegetarians. The content of minerals such as iron, manganese, and zinc were so relevant that the introduction of those monofloral bee pollens into diet could be an interesting alternative to avoid deficiencies. The antioxidant capacity of the products was greater than that reported for some red fruits, which are recognized as a dietary source of antioxidants. Monofloral bee pollen inhibited the growth of bacteria and yeast; however, the effect depends on the species tested. The phenolic profile of monofloral bee pollen is variable, and the products had 22-40 compounds, which were mostly identified. Flavonoid 3-O-glycosides glycosides predominated, but other compounds were also present, such as pinobanksin derivatives, glucosinolates, spermidine derivatives, a glycosylated anthocyanin, ampeloptin, eriodictyol, and ellagic acid. The type and the number of phenolic compounds can be due to the biological potential of monofloral bee pollen from Brazil. 


\section{ACKNOWLEDGMENTS}

The authors are grateful to beekeepers who provided samples. MM Moreira is also grateful to FCT/MEC and FEDER, under the Partnership Agreement PT2020 through the project UID/QUI/50006/2013 - POCI/01/0145/FERDER/007265.

\section{CONFLICT OF INTEREST}

The authors declare that they have no conflict of interest.

\section{ORCID}

Adriane Alexandre Machado De-Melo (D http://orcid.org/0000-0002$3522-4392$

\section{REFERENCES}

Abu-Reidah, I. M., Ali-Shtayeh, M. S., Jamous, R. M., Arráez-Román, D., \& Segura-Carretero, A. (2015). HPLC-DAD-ESI-MS/MS screening of bioactive components from Rhus coriaria L. (Sumac) fruits. Food Chemistry, 166, 179-191.

Almeida-Muradian, L. B., Arruda, V. A. S., \& Barreto, L. M. R. C. (2012). Manual de controle de qualidade do pólen apícola. São Paulo: APACAME.

Amíc, D., \& Lucic, B. (2010). Reliability of bond dissociation enthalpy calculated by the PM6 method and experimental TEAC values in antiradical QSAR of flavonoids. Bioorganic \& Medicinal Chemistry, 18, 28-35.

Arruda, V. A. S. (2013). Pólen apícola desidratado: Composição físico-química, qualidade microbiológica, compostos fenólicos e flavonoides, atividade antioxidante e origem botanica. Retrieved from http://www.teses.usp.br/ teses/disponiveis/9/9131/tde-22062015-172352/es.php

Bae, J. Y., Choi, J. S., Kang, S. W., Lee, Y. J., Park, J., \& Kang, Y. H. (2010). Dietary compound ellagic acid alleviates skin wrinkle and inflammation induced by UV-B irradiation. Experimental Dermatology, 19, 182-190.

Barth, O. M., Freitas, A. S., Oliveira, E. S., Silva, R. A., Maester, F. M., Andrella, R. R. S., \& Cardozo, G. M. B. Q. (2010). Evaluation of the botanical origin of commercial dry bee pollen load batches using pollen analysis: A proposal for technical standardization. Anais Da Academia Brasileira De Ciências, 82, 893-902.

Bassard, J. E., Ullmann, P., Bernier, F., \& Werck-Reichhart, D. (2010). Phenolamides: Bridging polyamines to the phenolic metabolism. Phytochemistry, 71(16), 1808-1824.

Brand-Williams, W., Cuvelier, M. E., \& Berset, C. (2005). Use of a free radical method to evaluate antioxidant. Food Science and Technology, 28, 25-30.

Bresciani, L., Calani, L., Cassu, M., Mena, P., Sayegh, M., Ray, S., \& Del-Rio, D. (2015). (Poly)phenolic characterization of three food supplements containing 36 different fruits, vegetables and berries. Pharma Nutrition, 3, 11-19.

Bystrom, L. M., Lewis, B. A., Brown, D. L., Rodriguez, E., \& Obendorf, R. L. (2008). Characterization of phenolics by LC-UV/vis, LC-MS/MS and sugars by GC in Melicoccus bijugatus Jacq. 'Montgomery' fruits. Food Chemistry, 111, 1017-1024.

Campos, M. G. R., Bogdanov, S., Almeida-Muradian, L. B., Szczesna, T., Mancebo, Y., Frigerio, C., \& Ferreira, F. (2008). Pollen composition and standardisation of analytical methods. Journal of Apicultural Research and Bee World, 47, 156-163.
Carpes, S. T., Prado, A., Moreno, I. A. M., Mourão, G. B., Alencar, S. M., \& Masson, M. L. (2008). Avaliação do potencial antioxidante do pólen apícola produzido na Região Sul do Brasil, Química Nova, 31, 1660-1664.

De-Melo, A. A. M. (2015). Perfil químico e microbiológico, cor, análise polínica e propriedades biológicas do pólen apícola desidratado. Retrieved from http://www.teses.usp.br/teses/disponiveis/9/9131/tde-18122 015-142742/pt-br.php

De-Melo, A. A. M., \& Almeida-Muradian, L. B. (2017). Chemical composition of bee pollen. In, J. M. Alvarez-Suarez (Ed.), Bee products chemical and biological properties (pp 2-259). Berlin: Springer International Publishing.

De-Melo, A. A. M., Estevinho, L. M., Sattler, J. A. G., Souza, B. R., Freitas, A. S., Barth, O. M., \& Almeida-Muradian, L. B. (2016). Effect of processing conditions on characteristics of dehydrated bee-pollen and correlation between quality parameters. LWT - Food Science and Technology, 65, 808-815.

Falcão, S. I., Vale, N., Gomes, P., Domingues, M. R. M., Freire, C., Cardoso, S. M., \& Vilas-Boas, M. (2013). Phenolic profiling of portuguese propolis by LC-MS spectrometry: Uncommon propolis rich in flavonoid glycosides. Phytochemical Analysis, 24, 309-318.

Féas, X., Vázquez-Tato, M. P., Estevinho, L., Seijas, J. A., \& Iglesias, A. (2012). Organic bee pollen: Botanical origin, nutritional value, bioactive compounds, antioxidant activity and microbiological quality. Molecules, 17, 8359-8377.

Festa, F., Aglitti, T., Duranti, G., Ricordy, R., Perticone, P., \& Cozzi, R. (2001). Strong antioxidant activity of ellagic acid in mammalian cells in vitro revealed by the comet assay. Anticancer Research, 21, 3903-3908.

Gouvêa, A. C. M. S., Araujo, M. C. P., Schulz, D. F., Pacheco, S., Godoy, R. L. O., \& Cabral, L. M. C. (2012). Anthocyanins standards (cyanidin3-O-glucoside and cyanidin-3-O-rutinoside) isolation from freezedried açaí (Euterpe oleraceae Mart.) by HPLC. Ciência e Tecnologia De Alimentos, 32, 43-46.

Huang, D., Ou, B., \& Prior, R. L. (2005). The chemistry behind antioxidant capacity assays. Journal of Agricultural and Food Chemistry, 53(6), 1841-1856.

Kajdzanoska, M., Gjamovski, V., \& Stefova, M. (2010). HPLC-DAD-ESIMS identification of phenolic compounds in cultivated strawberries from Macedonia. Macedonian Journal of Chemistry and Chemical Engineering, 29, 181-194.

Keckes, S., Gasic, U., Velickovic, T. C., Milojkovic-Opsenica, D., Natic, M., \& Tesic, Z. (2013). The determination of phenolic profiles of Serbian unifloral honeys using ultra-high-performance liquid chromatography/ high resolution accurate mass spectrometry. Food Chemistry, 138, 32-40.

Komosinska-Vassev, K., Olczyk, P., Kaźmierczak, J., Mencner, L., \& Olczyk, K. (2015). Bee pollen: Chemical composition and therapeutic application. Evidence-Based Complementary and Alternative Medicine, 2015, 1-6.

Koolen, H. H. F., Silva, F. M. A., Gozzo, F. C., Souza, A. Q. L., \& Souza, A. D. L. (2013). Antioxidant, antimicrobial activities and characterization of phenolic compounds from buriti (Mauritia flexuosa L. f.) by UPLCESI-MS/MS. Food Research International, 51, 467-473.

Leblanc, B. W., Davis, O. K., Boue, S., Delucca, A., \& Deeby, T. (2009). Antioxidant activity of Sonoran Desert bee pollen. Food Chemistry, 115(4), 1299-1305.

Lin, L. Z., \& Harnly, J. M. (2010). Identification of the phenolic components of chrysanthemum flower (Chrysanthemum morifolium Ramat). Food Chemistry, 120, 319-326.

Mărghitas, L. A., Stanciu, O. G., Dezmirean, D. S., Bobis, O., Popescu, O., Bogdanov, S., \& Campos, M. G. (2009). In vitro antioxidant capacity 
of honeybee-collected pollen of selected floral origin harvested from Romania. Food Chemistry, 115, 878-883.

Melo, I. L. P., Freitas, A. S., Barth, O. M., \& Almeida-Muradian, L. B. (2009). Relação entre a composição nutricional e a origem floral de pólen apícola desidratado. Revista Do Instituto Adolfo Lutz, 68 , 346-353.

Menezes, J. D. S., Maciel, L. F., Miranda, M. S., \& Druzian, J. I. (2010). Compostos bioativos e potencial antioxidante do pólen apícola produzido por abelhas africanizadas (Apis mellifera L.). Revista Do Instituto Adolfo Lutz, 69, 233-242.

Mihajlovic, L., Radosavljevic, J., Burazer, L., Smiljanic, K., \& Velickovic, T. C. (2015). Composition of polyphenol and polyamide compounds in common ragweed (Ambrosia artemisiifolia L.) pollen and sub-pollen particles. Phytochemistry, 109, 125-132.

Morais, M., Moreira, L., Feás, X., \& Estevinho, L. M. (2011). Honeybeecollected pollen from five Portuguese Natural Parks: Palynological origin, phenolic content, antioxidant properties and antimicrobial activity. Food and Chemical Toxicology, 49, 1096-1101.

Morgano, M. A., Martins, M. C. T., Rabonato, L. C., Milani, R. F., Yotsuyanagi, K., \& Rodriguez-Amaya, D. B. (2012). A comprehensive investigation of the mineral composition of brazilian bee pollen: Geographic and seasonal variations and contribution to human diet. Journal of the Brazilian Chemical Society, 23, 727-736.

Negri, G., Teixeira, E. W., Alves, M. L. T. M. F., Moreti, A. C. C. C., Otsuk, I. P., Borguini, R. G., \& Salatino, A. (2011). Hydroxycinnamic acid amide derivatives, phenolic compounds and antioxidant activities of extracts of pollen samples from Southeast Brazil. Journal of Agricultural and Food Chemistry, 59, 5516-5522.

Pascoal, A., Rodrigues, S., Teixeira, A., Féas, X., \& Estevinho, L. M. (2014). Biological activities of commercial bee pollens: Antimicrobial, antimutagenic, antioxidant and anti-inflammatory. Food and Chemical Toxicology, 63, 233-239.

Phenol-Explorer. (2015). Database on polyphenol content in foods. Retrieved from http://phenol-explorer.eu/
Rubilar, M., Pinelo, M., Shene, C., Sineiro, J., \& Nuñez, M. J. (2007). Separation and HPLC-MS identification of phenolic antioxidants from agricultural residues: Almond hulls and grape pomace. Journal of Agricultural and Food Chemistry, 55, 10101-10109.

Sakalem, M. E., Negri, G., \& Tabach, R. (2012). Chemical composition of hydroethanolic extracts from five species of the Passiflora genus. Revista Brasileira De Farmacognosia, 22, 1219-1232.

Saldanha, L. L., Vilegas, W., \& Dokkedal, A. L. (2013). Characterization of flavonoids and phenolic acids in Myrcia bella Cambess. Using FIA-ESIIT-MSn and HPLC-PAD-ESI-IT-MS combined with NMR. Molecules, 18(12), 8402-8416.

Shukla, S., \& Gupta, S. (2010). Apigenin: A promising molecule for cancer prevention. Pharmaceutical Research, 27(6), 962-978.

Truchado, P., Ferreres, F., \& Tomas-Barberan, F. A. (2009). Liquid chromatography-tandem mass spectrometry reveals the widespread occurrence of flavonoid glycosides in honey, and their potential as floral origin markers. Journal of Chromatography A, 1216, 7241-7248.

USDA. (2010). Database for the Oxygen Radical Absorbance Capacity (ORAC) of Selected Foods, Release 2. Retrieved from http://www.oracinfo-portal.de/download/ORAC_R2.pdf.

Vecchia, P. D., Pegoraro, B., Carpes, S. T., \& Pegoraro, A. (2009). Determinação de compostos fenólicos e flavonóides em pólen apícola coletado em Mandirituba-PR. In XIV SICITE - UTFPR, Vol. II.

WHO. (2012). Guideline: Sodium intake for adults and children. Geneva: World Health Organization.

How to cite this article: De-Melo AAM, Estevinho LM, Moreira MM, et al. Phenolic profile by HPLC-MS, biological potential, and nutritional value of a promising food: Monofloral bee pollen. J Food Biochem. 2018;42:e12536. https://doi.org/10.1111/jfbc. 12536 